http://economix.fr

\title{
Regulation, Institutions and Aggregate Investment: \\ New Evidence from OECD Countries
}

Document de Travail

Balázs Égert

Working Paper

2017-17 


\title{
REGULATION, INSTITUTIONS AND AGGREGATE INVESTMENT: NEW EVIDENCE FROM OECD COUNTRIES
}

\begin{abstract}
Balázs Égert *1
This paper investigates the relationship linking investment (capital stock) and structural policies. Using a panel of 32 OECD countries from 1985 to 2013, we show that more stringent product and labour market regulations are associated with less investment (lower capital stock). The paper also sheds light on the existence of non-linear effects of product and labour market regulation on the capital stock. Several alternative testing methods show that the negative influence of product and labour market regulation is considerably stronger at higher levels. The paper uncovers important policy interactions between product and labour market policies. Higher levels of product market regulations (covering state control, barriers to entrepreneurship and barriers to trade and investment) tend to amplify the negative relationships between product and labour market regulations and the capital stock. Equally important is the finding that the rule of law and the quality of (legal) institutions alters the overall impact of regulations on capital deepening: better institutions reduce the negative effect of more stringent product and labour market regulations on the capital stock, possibly through the reduction of uncertainty as regards the protection of property rights.
\end{abstract}

Keywords: aggregate investment, capital deepening, structural policy, product market regulation, labour market regulation, poliy interaction, OECD

* OECD, Economics Department, EconomiX at the University of Paris X-Nanterre; and CESifo. Email: balazs.egert@oecd.org

Many thanks go to Alain de Serres, Peter Gal, Catherine L. Mann and participants at the Second International Conference of the Society of Economic Measurement held in Paris on 22-24 July 2015 and the $4^{\text {th }}$ ISCEF conference in Paris on 14-16 April 2016 for useful comments and suggestions. The views expressed in this document represent those of the author and do not engage the OECD or any other institution the author is affiliated with. 


\section{Introduction}

There is a large body of literature, which looks at the drivers of aggregate investment. The empirical models used in existing studies rely on the accelerator model or the standard neoclassical models of investment, and in some rare cases, on Tobin's Q. Nevertheless, only a few studies analyse the relationship between product and labour market policies on the one hand and investment on the other. A large majority of the papers looking into the relationship between product market regulation and investment use sectoral and firm-level data. A few papers also investigate the extent to which investment is associated with labour market regulations.

This paper seeks to contribute to the literature on the link between product and labour market policies and aggregate investment for 32 OECD countries over 1985 to 2013. We analyse the effects of product and labour market policies on investment. We also go beyond the usual linear relationship. First, we study whether policies amplify or attenuate each other's effect on investment. We also test whether the relationship between policies and investment is non-linear in nature and whether the strength and direction of the relationship differs at different levels of regulation, and whether policy impacts are different when policies are being tightened or deregulated.

Our estimation results uncover a robust negative relationship between product and labour market policies and investment. Anticompetitive product market policies and more regulated labour markets tend to be associated with less investment. However, greater financial development, through an easier access to external finance, attenuates negative policy impacts. The estimation results provide evidence for non-linear policy effects and that the negative relationship between structural policies and investment is more pronounced if policies are being tightened rather than relaxed. We also show that product and labour market policies amplify each other's negative effect on investment and that the quality of institutions matter for the impact of regulations.

The remainder of this paper is organised as follows. Section 2 summarises possible ways of modelling investment. Section 3 provides a literature overview on the relationship between structural policies and investment. Section 4 deals with econometric and data issues and discusses modelling choices. Section 5 reports the estimation results. Finally, section 6 provides concluding remarks.

\section{Modelling investment}

\subsection{The accelerator model}

An accelerator model is a simple and commonly used way to model business investment. ${ }^{2}$ It assumes that investment $\left(I_{t}\right)$ can be split into net investment $\left(I^{N}\right)$ and replacement investment $\left(I^{R}\right)$. Replacement investment in period $t$ equals the depreciation of the capital stock in $t-1$ :

$$
I^{R}=\delta K_{t-1}
$$

where $\delta$ is the depreciation rate. Net investment is assumed to equal to changes in the desired capital stock:

$$
I^{N}=\sum_{i=0}^{n} \beta_{i} \Delta K_{t-i}^{*}
$$

\footnotetext{
${ }^{2}$ A strict definition of business investment is aggregate investment excluding housing investment and public investment. This type of investment can be called private business investment. Business investment according to OECD terminology excludes housing investment but includes public investment.
} 
In turn, the desired stock of capital $\left(K^{*}\right)$ is considered to be a linear function of output $(Y)$. Hence, real investment can be written as current and past real GDP growth and lagged capital stock: ${ }^{2}$

$$
I_{t}=\sum_{i=0}^{n} \beta_{i} \Delta Y_{t-i}+\delta K_{t-1}
$$

Equation (3) is usually estimated in constant domestic prices (Oliner et al., 1995; Lee and Rabanal, 2010; Barkbu et al., 2015; IMF, 2015). It can be easily transformed into a net investment equation: $I_{t}-\delta K_{t-1}=$ $\sum_{i=0}^{n} \beta_{i} \Delta Y_{t-i}$.

\subsection{The user cost of capital}

Obviously, investment can depend on more than just output growth and lagged capital stock. According to the neoclassical model, the desired stock of capital is not only a positive function of output but it also depends negatively on the user cost of capital (UCC) (Chirinko, 1993; Oliner et al., 1995):

$$
I_{t}=\sum_{i=0}^{n} \beta_{i} \Delta\left(Y_{t-i} U C C_{t-i}^{-\sigma}\right)+\delta K_{t-1}
$$

where $\sigma$ is a constant elasticity of substitution between capital and labour in the production function (Chirinko, 1993). Tevlin and Whelan (2003) argue that the capital stock is a non-stationary variable and propose a stationarised variant of equation (4) in growth rates:

$$
\frac{I_{t}}{K_{t-1}}=\propto+\sum_{i=0}^{n} \beta_{i} \Delta y_{t-i}+\sum_{i=0}^{n} \gamma_{i} \Delta u c c_{t-i}
$$

Fundamentally, there exists a long-run relationship linking the desired stock of capital to the level of output and the user cost of capital, which can be written as follows:

$$
K_{t}^{*}=\alpha Y_{t} \cdot U C C_{t}^{-\sigma}
$$

Log-linearisation and the error correction representation give the following equation: ${ }^{3}$

$$
\Delta k_{t}=\gamma k_{t-1}+\beta y_{t-1}+\delta u c c_{t-1}+\theta \Delta y_{t}+\pi \Delta u c c_{t}
$$

\subsection{Tobin's $Q$ and Euler equations}

Alternative models of business investment are Tobin's Q model and Euler equations. Tobin's Q links investment to the ratio of market value of corporate assets to the replacement cost of these assets. Euler equations are based on a dynamic optimisation problem of a representative firm wanting to maximise its present value and describe investment to its past linear and quadratic form (Bond and Meghir, 1994).

\subsection{Investment and structural policies}

Investment and capital deepening can depend on country characteristics including the ease with which funding is available to business. The business environment is also an important factor. If the direct and indirect costs of starting a business are low, the number of business start-ups will increase (World Bank, 2014). This in turn can translate into more investment. Similarly, pro-competitive product market regulation is likely to push firms to invest more to stay ahead of competitors or allow the entry of new competitors willing to invest. More relaxed labour market regulations allow for a less costly reallocation of capital and labour within and across firms and could, by lowering adjustment costs, encourage investment. 
To account for the impact of structural policies on the long-run level of investment, equation (6) could be augmented by product and labour market regulations, as in equation (8):

$$
K=f\left(Y, U C C^{-\sigma}, P M R, L M R\right)
$$

where PMR and LMR refer to product and labour market regulations. Pelgrin et al (2002) use a similar line of reasoning to plug in financial development as a driver of long-term business investment into the neoclassical investment model. ${ }^{3}$

\section{Literature overview of aggregate investment models}

\subsection{The comparative performance of benchmark investment models}

The consensus view emerging from the empirical literature is that Euler equations have not been very successful in explaining aggregate investment and perform poorly in forecasting aggregate investment (Oliner et al. 1995). Another common finding is that the Q model often fails to explain investment at the macroeconomic level (Oliner et al, 1995; Philippon, 2009). Philippon (2009) argues that using a Q ratio based on bond prices rather than equity prices helps improve the fit of aggregate investment equations. The difficulty with Tobin's $Q$ at the macro level is that it can be constructed using only firm level data on listed companies. Those data may not be representative for countries with predominantly bank finance. Also, market valuation of the assets of non-financial corporation at the macroeconomic level is bound to be subject to measurement errors, partly arising from equity market bubbles. Nevertheless, recent empirical work by the IMF (Lee and Rabanal, 2010; Barkbu et al., 2015) relied on the Q model for aggregate investment.

The empirical results on the neoclassical model are not much less controversial. It is difficult to identify sizeable negative effects of the cost of capital on aggregate investment. Several reasons may explain this finding. First, aggregate business investment may be unresponsive to the cost of capital due to aggregation bias. Such a bias can arise if different components of aggregate investment, such as investment in producers' durable equipment, ICT or commercial or industrial structures react differently to the cost of capital. Indeed, the elasticity to the cost of capital of investment in computers is considerably higher than that of aggregate investment (Tevlin and Whelan, 2003). Second, the elasticity of investment to the cost of capital can be low because estimations are usually carried out for the dynamic relationship, that is for investment and changes in the cost of capital.

Yet looking at the long-term relationship between the stock of capital and the cost of capital in a cointegration framework may yield higher elasticities. In addition, OLS estimates often reported in the literature tend to underestimate the elasticity due to a small sample bias. Caballero (1994) shows that this bias is very large for the case of the US economy. Nevertheless, this result cannot be generalised for a more recent and longer period. Lee and Rabanal (2010) reports considerably lower elasticities than Caballero (1994). Third, results reported in Tevlin and Whelan (2003) suggest that the small effect of the cost of capital on investment is largely a result of the low interest rate elasticity. Separating the cost of capital into relative prices and the interest rate component shed light on a sizeable negative correlation between relative prices and investment, and the almost zero interest elasticity of investment (Tevlin and Whelan, 2003). Studies looking at different periods and a variety of countries confirm this finding

\footnotetext{
${ }^{3}$ Pelgrin et al. (2002) use real investment rather than the capital stock as the dependent variable in equation (8). They argue that in the steady state, investment can be written as a constant share of the capital stock if one assumes a constant growth rate of the capital stock: $I=(\delta+g) K$ where $\delta$ is the depreciation rate and $g$ is output growth in the steady-state. In practice, the capital stock can be replaced by investment if the historical investment to capital stock ratio is a stationary process. This is, however, not always the case in practice.
} 
(Banerjee et al, 2015; and Barkbu et al. 2015) or even find a positive correlation between interest rates and investment (Kothari et al., 2014). Explanations for the missing interest rate effects range from simultaneity bias to the fact that aggregate interest rate series do not reflect the interest component of investment (Sharpe and Suarez, 2014).

A systematic comparison of alternative models indicates that the accelerator model outperformed the other investment models until the early 1990s (Oliner et al., 1995). Nevertheless, the accelerator model had problems of capturing the investment boom in the mid- and late-1990s. The failure of the accelerator model arises from the substantial rise in investment in computer equipment, which, through composition effects, increased the average depreciation rate. Separating computer and non-computer investment helps regain confidence in the accelerator model (Tevlin and Whelan, 2003).

Overall, most studies looking into the impact of structural policies on investment are not fully in line with the reference investment models. The dependent variable is investment as a share of GDP or as a share of the capital stock. The accelerator model and its augmented versions use the real capital stock as a dependent variable. The accelerator model includes real GDP as a regressor. This variable is often missing from the empirical estimations. In addition, the lagged dependent investment variable is also very frequently included in empirical models of investment. The accelerator model and its extensions would not contain this variable.

\subsection{Investment and structural policies}

\subsubsection{Product market regulation}

The literature looking into the structural drivers of aggregate investment is relatively thin. There is some empirical evidence that the degree of product market regulation correlates with investment outcomes. Nevertheless, this link is not very robust. A majority of papers analysing the connection between product market regulation and investment relies on sectoral data. Two of them (Alesina et al., 2005; Égert, 2009) look only at the seven network sectors for which the OECD's Energy Transport and Communications Regulation (ETCR) indicator is available: electricity and gas, post and telecommunications, road freight, air and rail transport. They find a strong negative correlation between barriers to entry and investment: higher barriers to entry are associated with lower investment in those sectors. Vartia (2008) covers all sectors of the economy and employ the OECD's regulatory impact indicator. This indicator captures the extent to which any given sector is influenced by regulation in network industries through intermediate inputs. The results tend to show a negative relationship but they are not overly robust to alternative model specifications. Another string of papers uses firm-level data in network industries and report mixed results. Araujo (2011) is able to identify some weak negative relationship between barriers to entry and investment but Cambini and Rondo (2011) cannot pin down such a relationship between overall regulation and public ownership on the one hand and investment on the other.

Kerdrain et al. (2010), the only paper looking at country-level investment, report statistically significant coefficient estimates on the OECD's ETCR indicator for a panel of OECD countries. By contrast, extending the sample to 117 countries and using components of the World Bank's Doing Business indicator, they shed light on a negative and precisely estimated relationship between investment and the number of procedure to register a business and the cost of starting a business. The coefficient estimates on the overall Doing Business indicator are statistically not significant. The same applies to the indicator measuring the days required to start a business. 


\subsubsection{Labour market regulation}

At the macroeconomic level and for several OECD countries, there is no evidence that labour market regulation has any impact of investment. Kerdrain et al (2010) finds statistically non-significant coefficient estimates for the overall Employment Protection Legislation (EPL) indicator as well as for its components on temporary and permanent contracts.

There is mixed evidence on the relation between capital stock and labour market regulation at the firm and industry level. ${ }^{4}$ Autor et al. (2007) document for US firms that higher firing costs (wrongful discharge exceptions) are linked to higher capital stock and capital-to-labour ratios. But they show that the effect becomes negative when state-specific trends are used. The paper also suggests that a rise in capital may be related to a correction of an earlier downturn and that the introduction of more stringent firing regulations followed a rise in the capital-to-labour ratio. Using a panel of European firms, Cingano et al. (2010) find that more stringent EPL reduces investment per worker and capital per worker. By contrast, focusing only on Italian firms, Cingano et al. (2015) show that the introduction of unjust-dismissal costs raises the capital-to-labour ratio in firms with less than 15 employees, compared to larger firms. Finally, according to Cette et al. (2016), at the sector level ${ }^{5}$, more stringent EPL has a positive effect on non-ICT capital, a nonsignificant effect on ICT capital and impacts negatively R\&D capital

\subsubsection{Financial development}

Past work has analysed the relation between financial development and investment. This strand tends to find that more developed capital markets and an easier access to bank credit, usually captured by the private credit-to-GDP ratio, tend to go hand in hand with a higher level of investment. Both Bassanini et al. (2001) and Pelgrin et al. (2002) report for a set of industrialised OECD countries a strong positive correlation between stock market capitalisation and private credit over GDP on the one hand, and private business investment on the other hand. For a more recent sample and aggregate investment rather than private business investment, Kerdrain et al. (2010) identify a positive correlation between financial liberalisation and investment but could not find a statistically significant positive correlation between stock markets (market capitalisation and turnover) and investment. Salotti and Trecroci (2012) also find it difficult to pin down a positive relation between private credit and investment. Identifying a strong positive correlation between financial development and investment is not an easy task for emerging and developing countries. For instance, Luca and Spatafora (2012) and Lim (2014) report weak evidence for such a link for panels including over 100 countries. Empirical evidence in Ghura and Goodwin (2010) is mixed for a group of 31 emerging and developing countries.

\footnotetext{
${ }^{4}$ More stringent EPL can increase the capital-to-labour ratio by raising the cost of labour. In the absence of financial and labour market frictions, firms can decide to substitute capital for labour. But in the case of market frictions and wage bargaining, higher EPL decreases the capital-to-labour ratio (Cingano et al. 2015).

${ }^{5}$ For 14 OECD countries and based on a difference-in-difference approach.
} 
Table 1. Empirical estimations including product and labour market regulation indicators

\begin{tabular}{|c|c|c|c|c|c|}
\hline Paper & $\begin{array}{c}\text { Country \& time } \\
\text { coverage }\end{array}$ & Investment & PMR & $\begin{array}{r}\text { Results } \\
\text { LMR }\end{array}$ & $\begin{array}{c}\text { Financial } \\
\text { development }\end{array}$ \\
\hline \multicolumn{6}{|c|}{ Macro-level studies } \\
\hline Kerdrain et al. (2010) & $\begin{array}{l}30 \text { OECD } \\
\text { countries; 1965- } \\
2008 \\
\\
117 \text { countries, } \\
1993-2008\end{array}$ & $\begin{array}{l}\text { Total, with lagged investment } \\
\text { (\% GDP) } \\
\text { Total, with lagged investment } \\
\text { (\% GDP) }\end{array}$ & $\begin{array}{l}\text { ETCR: no effect } \\
\begin{array}{l}\text { negative effect : number of } \\
\text { procedures to register a } \\
\text { business, cost of starting a } \\
\text { business }\end{array}\end{array}$ & EPL: no effect & $\begin{array}{l}\text { positive effect : financial } \\
\text { liberalisation } \\
\text { no effect : stock markets } \\
\text { (market capitalisation and } \\
\text { turnover }\end{array}$ \\
\hline $\begin{array}{l}\text { Salotti and Trecroci } \\
\text { (2012) }\end{array}$ & $\begin{array}{l}20 \text { OECD } \\
\text { countries; } 1970- \\
2009\end{array}$ & Private & & & $\begin{array}{l}\text { no effect : private credit to } \\
\text { GDP }\end{array}$ \\
\hline $\begin{array}{l}\text { Luca and Spatafora } \\
\text { (2012)) }\end{array}$ & $\begin{array}{l}103 \text { emerging and } \\
\text { developing } \\
\text { countries; 2001- } \\
2007\end{array}$ & Total & & & $\begin{array}{l}\text { weak positive effect : } \\
\text { private credit to GDP }\end{array}$ \\
\hline $\begin{array}{l}\text { Ghura and Goodwin } \\
\text { (2010) }\end{array}$ & $\begin{array}{l}31 \text { emerging and } \\
\text { developing } \\
\text { countries; } 1975- \\
1992\end{array}$ & Private & & & $\begin{array}{l}\text { mixed evidence : private } \\
\text { credit to GDP }\end{array}$ \\
\hline $\operatorname{Lim}(2014)$ & $\begin{array}{l}\text { Around } 130 \\
\text { countries; } 1980- \\
2009\end{array}$ & Total, with lagged investment & & & $\begin{array}{l}\text { weak positive effect : } \\
\text { private credit to GDP }\end{array}$ \\
\hline Bassanini et al. (2001) & $\begin{array}{l}21 \text { OECD } \\
\text { countries; } 1971- \\
1998\end{array}$ & Private business (\% GDP) & & & $\begin{array}{l}\text { positive effect : stock } \\
\text { market capitalisation and } \\
\text { private credit to GDP }\end{array}$ \\
\hline Pelgrin et al. (2002) & $\begin{array}{l}18 \text { OECD } \\
\text { countries; } 1977- \\
1999\end{array}$ & Private business (\% of GDP) & & & $\begin{array}{l}\text { positive effect : stock } \\
\text { market capitalisation and } \\
\text { private credit to GDP }\end{array}$ \\
\hline \multicolumn{6}{|c|}{ Sector-level panel studies } \\
\hline Alesina et al. (2005) & \begin{tabular}{|l|}
21 OECD \\
countries, 1975- \\
1998
\end{tabular} & $\begin{array}{l}\text { Total, sector level, with } \\
\text { lagged inv. }\end{array}$ & $\begin{array}{l}\text { negative effect : barriers to } \\
\text { entry and ETCR }\end{array}$ & & \\
\hline Egert (2009) & $\begin{array}{l}13 \text { OECD } \\
\text { countries, 1975- } \\
2006\end{array}$ & $\begin{array}{l}\text { Sector level, network } \\
\text { sectors, lagged inv. }\end{array}$ & $\begin{array}{l}\text { negative effect : barriers to } \\
\text { entry and ETCR }\end{array}$ & & \\
\hline Cette et al. (2016) & $\begin{array}{l}14 \text { OECD } \\
\text { countries, 1988- } \\
2007\end{array}$ & $\begin{array}{l}\text { non-ICT, ICT, R\&D capital, } \\
\text { K/L }\end{array}$ & & $\begin{array}{l}\text { positive effect on non-ICT capital; } \\
\text { no effect on ICT capital, negative } \\
\text { effect on R\&D capital }\end{array}$ & \\
\hline Vartia (2008) & $\begin{array}{l}16 \text { OECD } \\
\text { countries, 1981- } \\
2001\end{array}$ & $\begin{array}{c}\text { Business, sector level, with } \\
\text { lagged inv. }\end{array}$ & $\begin{array}{l}\text { weak negative effect : } \\
\text { regulatory impact indicator }\end{array}$ & & \\
\hline \multicolumn{6}{|c|}{ Firm-level studies } \\
\hline Araujo (2011) & $\begin{array}{l}28 \text { OECD } \\
\text { countries, 1980- } \\
2006\end{array}$ & $\begin{array}{l}\text { Firm-level investment in } \\
\text { network sectors }\end{array}$ & $\begin{array}{l}\text { weak negative effect : } \\
\text { barriers to entry }\end{array}$ & & \\
\hline Cambini (2010) & $\begin{array}{l}15 \text { OECD } \\
\text { countries, 1994- } \\
2004\end{array}$ & $\begin{array}{l}\text { Firm-level investment in } \\
\text { network sectors }\end{array}$ & $\begin{array}{l}\text { no effect : ETCR, public } \\
\text { ownership }\end{array}$ & & \\
\hline Autor et al. (2007) & $\begin{array}{l}\text { USA, firm-level } \\
\text { study }\end{array}$ & $\begin{array}{c}\text { capital stock, capital/labour } \\
\text { ratio }\end{array}$ & & EPL: positive effect on capital & \\
\hline Cingano et al. (2010) & European firms & capital/labour ratio & & EPL: negative effect on capital & \\
\hline Cingano et al. (2015) & Italian firms & capital/labour ratio & & EPL: positive effect on capital & \\
\hline
\end{tabular}




\section{Modelling and data issues}

\subsection{Testable equations}

\subsubsection{Linear specifications}

Our baseline equation includes the real stock of capital as the dependent variable. Real output, the user cost of capital and product market regulation are used as regressors:

$$
K_{j, t}=f\left(Y_{j, t}, U C C_{j, t}, P M R_{j, t}\right)
$$

Equation (9) implies that the capital stock depends on the level of real output, user cost and the level of product market regulation. The user cost of capital is decomposed into i.) long-term real interest rate, ii.) corporate taxes, and iii.) relative investment prices. The level of the stringency of product market regulation is captured by the OECD's Energy Transport and Communications Regulation (ETCR) indicator. Tighter regulation can be expected to result in less investment and a lower capital stock in the long run.

Equation (9) is augmented by including labour market regulation (LMP):

$$
K_{j, t}=f\left(Y_{j, t}, U C C_{j, t}, P M R_{j, t}, L M P_{j, t}\right)
$$

Labour market regulations are measured the OECD's Employment Protection Legislation (EPL) indicator (for permanent contracts). ${ }^{6}$ Higher values indicate more strict regulation. The literature overview suggests that the relationship between labour market regulation and the capital stock is ambiguous: it can be either positive or negative.

Finally, measures of financial development (FD) such as private credit to the economy and measures of stock market deepening (stock market capitalisation and turnover) are added to equation (10):

$$
\left.K_{j, t}=f\left(Y_{j, t}, U C C_{j, t}, P M R_{j, t}, L M P_{j, t}, F D_{j, t}\right)\right)
$$

\subsubsection{Non-linear specifications}

\section{$\underline{\text { Smooth and threshold non-linearities and asymmetric effects }}$}

Policies could have an increasingly or decreasingly negative impact on the capital stock (smooth nonlinearity, equation 12).

$$
K_{j, t}=f\left(Y_{j, t}, U C C_{j, t}, P M R_{j, t}, L M R_{j, t}, F D_{j, t}, P M R_{j . t}^{2}, L M R_{j, t}^{2}, F D_{j, t}^{2}\right)
$$

The impact of regulation could be different at high and low levels of regulation (threshold non-linearity). Equation (13) shows this type of effect when the variable of interest has different coefficients below and above the tipping point of the threshold variable. If the threshold variable is the same variable, this is a classical 'univariate' non-linear effect. If the threshold variable is another policy variable, the results are comparable to interactions. For instance, the impact of labour market policies could depend on the level of

\footnotetext{
${ }^{6}$ Other variables such as the labour tax wedge, spending on active labour market policies (ALMP) and the unemployment benefit replacement ratio were also look at. Results were not conclusion. Therefore, these variables are not presented in the paper (except for ALMP in Table 6b).
} 
restrictiveness of product market regulation. The threshold value is determined endogenously through a grid search: A grid search with steps of $1 \%$ of the distribution is carried out to find the value of the threshold variable that minimises the sum of squared residuals of the estimated two-regime model. The grid search starts at $15 \%$ of the distribution and stops at $85 \%$ to ensure that a sufficient number of observations falls into each regime. There is evidence for non-linearity if the null hypothesis of $\beta_{1}=\beta_{2}$ can be rejected against the alternative hypothesis of $\beta_{1} \neq \beta_{2}$.

$$
K_{j, t}=\left\{\begin{array}{lll}
\alpha_{1}+\alpha_{2} Y_{j, t}+\alpha_{3} U C C_{j, t}+\alpha_{4} L M R_{j, t}+\alpha_{5} F D_{j, t}+, \beta_{1} P M R_{j, t}+\varepsilon_{t} & \text { if } & P M R<T \\
\alpha_{1}+\alpha_{2} Y_{j, t}+\alpha_{3} U C C_{j, t}+\alpha_{4} L M R_{j, t}+\alpha_{5} F D_{j, t}+, \beta_{2} P M R_{j, t}+\varepsilon_{t} & \text { if } & P M R \geq T
\end{array}\right.
$$

Finally, the impact of regulation could be different depending on the direction of the change in regulation, e.g. if regulation is being tightened or relaxed (asymmetric effect). Equation (14) helps test these nonlinear effects. Again, we can conclude in favour of an asymmetric effect if the null hypothesis of $\beta_{1}=\beta_{2}$ can be rejected against the alternative hypothesis of $\beta_{1} \neq \beta_{2}$.

$$
K_{j, t}=\left\{\begin{array}{lll}
\alpha_{1}+\alpha_{2} Y_{j, t}+\alpha_{3} U C C_{j, t}+\alpha_{4} L M R_{j, t}+\alpha_{5} F D_{j, t}+, \beta_{1} P M R_{j, t}+\varepsilon_{t} & \text { if } & \Delta P M R<0 \\
\alpha_{1}+\alpha_{2} Y_{j, t}+\alpha_{3} U C C_{j, t}+\alpha_{4} L M R_{j, t}+\alpha_{5} F D_{j, t}+, \beta_{2} P M R_{j, t}+\varepsilon_{t} & \text { if } & \Delta P M R \geq 0
\end{array}\right.
$$

\section{Policy interactions: the long-term effect}

The impact of one policy could depend on the level of another policy. Threshold regressions allow for two (or more) regimes. Using interactions in the regressions would allow a smoother dependence on the threshold variable. For instance, interacting the time-varying ETCR indicator with a measure of EPL, which is calculated as a country average over the sample period (and demeaned across countries) would tell us by how much the overall coefficient on ETCR would change if a country moves away from the cross-country average (equation 15a).

This type of analysis can be extended to the time-invariant measures of product market regulations (PMR subcomponents), measures of the ease of doing business and indicators capturing the quality of institutions. Some policies such as institutions change slowly over time and can be observed at high intervals or we only have a couple of observations of them. These variables cannot be used as determinants of investment in regressions with country fixed effects (because country fixed effects capture these variables) but could be interacted with the time varying variables. In this case, the interaction term would tell whether the impact of a product or labour market policy would depend on the level of these institutions or other policies (equation 15b).

$$
\begin{aligned}
K_{j, t} & =f\left(Y_{j, t}, U C C_{j, t}, P M R_{j, t}, L_{L M R_{j, t}}, F D_{j, t}, P M R_{j, t} * \overline{L M R_{j}}\right) \\
K_{j, t} & =f\left(Y_{j, t}, U C C_{j, t}, P M R_{j, t} * \overline{\text { INSTITUTIONS }_{j}}\right)
\end{aligned}
$$

\section{Policy interactions: the impact on the speed of adjustment}

Finally, cross-country variations in policies and institutions could also have an influence on the speed of adjustment in the error correction model. In such cases, the time which is required to reach the long-run equilibrium will depend on the level of policies across countries (the deviation from the cross-country mean). This relationship is estimated based on equation (16) below where $\hat{\varepsilon}_{t-1}$ is the lagged deviation from equilibrium obtained from the first-stage long-term model of our estimation strategy (see section 4.4): 


$$
\Delta K_{j, t}=f\left(\hat{\varepsilon}_{t-1}, \hat{\varepsilon}_{t-1} * \overline{\text { INSTITUTIONS }}\right)
$$

\subsection{Data sources and definitions}

The capital stock series are drawn from OECD databases and relate to business capital stock (total minus housing). The component of the user costs of capital, that is the long-term real interest rate, relative investment prices and corporate taxes are calculated using data obtained from various OECD databases (see Table 2 hereafter).

The baseline models are estimated for a panel including 32 OECD countries and covering the period from 1985 to 2013. The corporate tax variables are not available for Mexico and Chile. This reduces our sample from the complete sample of 34 OECD countries to 32 (all other variables are available for all OECD countries). Our sample encompasses about 30 years, because the capital stock series obtained from OECD sources start in 1985. Otherwise, most other variables, except the stock market indicators, are available at least from the mid-1970.

More stringent regulation in various parts of the economy, including labour and product markets, can impede the efficient allocation of capital and labour within and across firms and industries. This can impact negatively on investment. Product market regulation could be captured by the OECD's Product Market Regulation (PMR) indicator or the World Bank's Doing Business indicator. The drawback of the PMR indicator is that it is available every five years (1998, 2003, 2008 and 2013). ${ }^{7}$ The Doing Business indicators are available at annual frequency. However, it only covers the period from 2002 to 2014.

The OECD's electricity, transport and communications regulation (ETCR) indicator, a subset of the OECD's Product Market Regulation (PMR) indicator, covers a longer period as it starts in 1975 and ends in 2013. It also has annual observations. For these two reasons, this paper uses the ETCR indicator, which measures the degree of product market regulation on a scale of 0 to 6 . Low numbers indicate less regulation, higher numbers refer to more stringent regulation.

In addition to product market regulation, labour market regulation can also bear an impact on MFP through the direct effects of the allocation of labour resources and the indirect impact on capital reallocation. Therefore, we use the OECD's employment protection legislation (EPL) indicator (for permanent contracts). They are borrowed from Gal and Theising (2015), which provide details on data sources and definitions.

In line with the literature, three measures of financial system development are used: private credit to GDP to measure the ease of access to bank credit, and two measures of stock market deepening: stock market capitalisation and stock market turnover as a share of GDP. The stock market indicators are shorter than any other variables. To limit the loss of observations, they will not be used in a systematic fashion.

Four groups of time-invariant variables are interacted with the time-varying product and labour market regulation indicators.

- The first group includes the country averages of the time varying policy variables (such as ETCR and EPL).

\footnotetext{
${ }^{7}$ Westmore (2013) and Andrews and Westmore (2014) use the PMR indicator by filling in the gaps between the observations in 1998, 2003, 2008 and 2013 via linear interpolation.
} 
- The second group relates to sub-groups of the OECD’s Product Market Indicators (PMR). The headline PMR indicator and its two-level disaggregated sub-indices (state control, barriers to entrepreneurship; and barriers to trade and investment) are used. These series are available from 1998 to 2013 at five year intervals. For each country, the average of the available observations is employed.

- The third group includes the ease of doing business (the time and cost of insolvency and starting a business). These data are obtained from the World Bank's World Development Indicators database.

- The fourth group includes variables capturing the quality of institutions (e.g. rule of law and the quality of the legal system). The rule of law variable comes from the World Bank's World Development Indicators database. The quality of the legal system is drawn from the Fraser Institute's Economic Freedom of the World database. For each country, the mean of the available observations is calculated and used in the estimations. 
Table 2. Variable definitions and sources

\begin{tabular}{|c|c|c|c|c|}
\hline Variables & Definition & Source & Max time span & Countries \\
\hline \multicolumn{5}{|l|}{ TIME-VARYING VARIABLES } \\
\hline \multicolumn{5}{|l|}{ Capital stock } \\
\hline $\begin{array}{l}\text { real capital stock } \\
\text { real capital stock / real output }\end{array}$ & $\begin{array}{l}\text { real capital stock (total - housing) } \\
\text { real capital stock (total - housing) / real GDP }\end{array}$ & $\begin{array}{l}\text { OECD Economic Outlook } \\
\text { DB } \\
\text { OECD Economic Outlook } \\
\text { DB }\end{array}$ & $\begin{array}{l}1985-2013 \\
1985-2013\end{array}$ & $\begin{array}{l}34 \\
34\end{array}$ \\
\hline \multicolumn{5}{|l|}{ User cost of capital } \\
\hline $\begin{array}{l}\text { real long-term interest rate } \\
\text { relative price of investment } \\
\text { corporate taxes }\end{array}$ & $\begin{array}{l}\text { long-term nominal interest rate deflated using the GDP } \\
\text { deflator: rirl=((1+irl/100)/(1+dpgdp/100)-1 })^{\star} 100 \\
\text { investment deflator over GDP deflator } \\
\text { measure 1: corporate tax revenues over GDP }\end{array}$ & $\begin{array}{l}\text { OECD Economic Outlook } \\
\text { DB } \\
\text { OECD Economic Outlook } \\
\text { DB } \\
\text { OECD Revenue Statistics } \\
\end{array}$ & $\begin{array}{r}1961-2013 \\
1960-2013 \\
1965-2013 \\
\end{array}$ & $\begin{array}{l}34 \\
34 \\
32\end{array}$ \\
\hline \multicolumn{5}{|l|}{ Product market regulations } \\
\hline ETCR all & $\begin{array}{l}\text { Regulation in Electricity, Transport and Communication } \\
\text { (ETCR) }\end{array}$ & OECD PMR Database & $1975-2013$ & 34 \\
\hline \multicolumn{5}{|l|}{ Labour market regulations } \\
\hline EPL & the employment protection legislation (EPL) indicator for perm & OECD ELS statistics & $1985-2013$ & 34 \\
\hline \multicolumn{5}{|l|}{ Financial development } \\
\hline $\begin{array}{l}\text { private credit to GDP ratio } \\
\text { stock market capitalisation ( } \% \text { GDP) } \\
\text { stock market turnover ( } \% \text { GDP) }\end{array}$ & $\begin{array}{l}\text { domestic credit to the private sector, \% of GDP } \\
\text { stock market capitalisation over GDP } \\
\text { stock market turnover over GDP }\end{array}$ & $\begin{array}{l}\text { World Bank WDI } \\
\text { World Bank WDI } \\
\text { World Bank WDI }\end{array}$ & $\begin{array}{l}1960-2013 \\
1988-2012 \\
1988-2012 \\
\end{array}$ & $\begin{array}{l}34 \\
34 \\
34 \\
\end{array}$ \\
\hline \multicolumn{5}{|c|}{\begin{tabular}{l|l} 
CONSTANTS USED FOR INTERACTIONS & \\
\end{tabular}} \\
\hline \multicolumn{5}{|l|}{ Product market regulation (PMR) indicator } \\
\hline $\begin{array}{l}\text { overall PMR indicator } \\
\text { State contol } \\
\text { public ownership } \\
\text { involvement in business operations } \\
\text { Barriers to entrepreneurship } \\
\text { complexity of regulatory procedures } \\
\text { administrative burden on startups } \\
\text { Regulatory protection on incumbents } \\
\text { Barriers to trade\&investment } \\
\text { expllicit barriers } \\
\text { other barriers }\end{array}$ & & & $\begin{array}{c}\text { 1998-2013, } \\
\text { 5-year intervals }\end{array}$ & 34 \\
\hline \multicolumn{5}{|l|}{ Business environemnt } \\
\hline $\begin{array}{l}\text { time of insolvency procedures } \\
\text { cost of insolvency procedures } \\
\text { recovery rate - insolvency procedure } \\
\text { time of starting a business } \\
\text { cost of starting a business } \\
\text { time of contract enforcemet } \\
\text { cost of contract enforcement }\end{array}$ & $\begin{array}{l}\text { resolving insolvency, years } \\
\text { resolving insolvency, \% of estate } \\
\text { as cents on the dollar recovered by secured creditors } \\
\text { days } \\
\% \text { of GNI per capita } \\
\text { days } \\
\% \text { of the claim }\end{array}$ & $\begin{array}{l}\text { World Bank WDI } \\
\text { World Bank WDI } \\
\text { World Bank WDI } \\
\text { World Bank WDI }\end{array}$ & $\begin{array}{l}2004-2012 \\
2004-2012 \\
2004-2012 \\
2004-2012\end{array}$ & $\begin{array}{l}34 \\
34 \\
34 \\
34\end{array}$ \\
\hline \multicolumn{5}{|l|}{ Institutions } \\
\hline $\begin{array}{l}\text { rule of law } \\
\text { quality of legal system } \\
\text { quality of legal system - law enforcement } \\
\text { quality of legal system - judicial independe }\end{array}$ & & $\begin{array}{l}\text { World Bank WDI } \\
\text { Fraser Institute's Economic } \\
\text { Freedom of the World }\end{array}$ & \begin{tabular}{|c|}
$2004-2012$ \\
$1980-2012$ \\
5 -year intervals \\
before 2000 and \\
annual \\
afterwards
\end{tabular} & 34 \\
\hline
\end{tabular}

Source: OECD

\subsection{Descriptive statistics and preliminary data analysis}

Table 3a provides some descriptive statistics of the capital stock series, the policy variables and the control variables $^{8}$. A number of interesting features emerge. Looking at the various measures of standard deviation indicates that the capital stock, the real GDP series and to a lesser extent the EPL indicator vary a lot across countries with much less so over time (once country fixed effects are taken out of the series). At the same time, most of the policy variables exhibit a substantial average within-country (as opposed to cross-

\footnotetext{
${ }^{8}$ Table 3 reports descriptive statistics for the common sample for all variables. Results are very similar for common samples obtained for less policy variables.
} 
country) variation, even after controlling for common year fixed effects. Table 3b gives an overview of the cross-country features of the time-invariant variables

Table 3a Descriptive statistics - time-varying variables

\begin{tabular}{|c|c|c|c|c|c|c|c|c|c|c|c|c|}
\hline & \multicolumn{4}{|c|}{ with CFE \& TFE } & \multicolumn{4}{|c|}{ without CFE } & \multicolumn{4}{|c|}{ without CFE and TFE } \\
\hline & Min & $\operatorname{Max}$ & Mean & Sdev & Min & $\operatorname{Max}$ & Mean & Sdev & Min & $\operatorname{Max}$ & Mean & Sdev \\
\hline log real capital stock & 24.93 & 35.96 & 28.53 & 2.33 & -0.55 & 0.47 & 0.00 & 0.17 & -0.24 & 0.18 & 0.00 & 0.06 \\
\hline log (real capital stock / real output) & 0.23 & 1.44 & 0.76 & 0.26 & -0.29 & 0.34 & 0.00 & 0.07 & -0.26 & 0.27 & 0.00 & 0.06 \\
\hline real output & 24.18 & 34.81 & 27.77 & 2.19 & -0.47 & 0.28 & 0.00 & 0.15 & -0.26 & 0.15 & 0.00 & 0.05 \\
\hline corporate tax / GDP & 0.30 & 12.80 & 3.00 & 1.32 & -3.89 & 6.71 & 0.00 & 0.88 & -3.34 & 5.76 & 0.00 & 0.74 \\
\hline log relative price of investment & -0.11 & 0.29 & 0.05 & 0.08 & -0.18 & 0.22 & 0.00 & 0.05 & -0.14 & 0.13 & 0.00 & 0.03 \\
\hline long-term real interest rate & -7.11 & 10.95 & 3.36 & 2.32 & -10.18 & 7.25 & 0.00 & 2.21 & -8.81 & 7.03 & 0.00 & 1.63 \\
\hline ETCR & 0.97 & 5.53 & 3.02 & 1.08 & -1.76 & 2.50 & 0.00 & 0.91 & -1.20 & 1.05 & 0.00 & 0.33 \\
\hline EPL & 0.26 & 5.00 & 2.15 & 0.90 & -0.45 & 0.89 & 0.00 & 0.15 & -0.38 & 0.83 & 0.00 & 0.14 \\
\hline private credit / GDP & 26.54 & 227.75 & 111.59 & 47.74 & -68.32 & 91.76 & 0.00 & 25.79 & -77.54 & 57.42 & 0.00 & 18.76 \\
\hline stock market capitalisation & 0.02 & 434.92 & 59.92 & 65.57 & -138.86 & 269.43 & 0.00 & 46.71 & -91.11 & 219.53 & 0.00 & 32.45 \\
\hline stock market turnover & 0.15 & 404.07 & 80.39 & 56.21 & -98.85 & 256.70 & 0.00 & 40.48 & -90.87 & 206.60 & 0.00 & 31.41 \\
\hline output gap & -5.04 & 8.79 & 0.07 & 1.61 & -5.16 & 8.29 & 0.00 & 1.61 & -4.28 & 7.54 & 0.00 & 1.15 \\
\hline
\end{tabular}

Note:' with CFE \& TFE': original series, 'without CFE': residuals from regressions in which the series are regressed on country fixed effects only.' without CFE \&TFE': residuals from regressions in which the series are regressed on country and time fixed effects only.

Table 3b Descriptive statistics - time-invariant variables

\begin{tabular}{l|cccc|} 
& Min & Max & Mean & Sdev \\
\hline PMR \& sub-components & & & & \\
aggregate indicator & 1.18 & 2.80 & 1.73 & 0.35 \\
$\quad$ state control & 1.51 & 3.92 & 2.41 & 0.54 \\
$\quad$ barriers to entrepreneurship & 1.49 & 3.07 & 2.06 & 0.37 \\
$\quad$ barriers to trade and investment & 0.20 & 2.09 & 0.74 & 0.41 \\
Doing business & & & & \\
contract enforcement - cost & 8.31 & 38.63 & 21.46 & 7.81 \\
contract enforcement - time & 216 & 1332 & 517 & 260 \\
insolvency - costs & 1.00 & 23.00 & 9.60 & 5.97 \\
insolvency - time & 0.40 & 5.84 & 1.92 & 1.16 \\
insolvency - recovery rate & 18.41 & 92.85 & 65.40 & 21.66 \\
starting a business - cost & 0.05 & 20.69 & 6.80 & 6.42 \\
starting a business - time & 2.71 & 61.08 & 16.83 & 11.68 \\
Institutions & & & & \\
rule of law & -0.53 & 1.94 & 1.27 & 0.60 \\
legal system & 4.86 & 8.54 & 7.27 & 1.07
\end{tabular}

Source: OECD 
Table 4 Correlations

\begin{tabular}{|c|c|c|c|c|c|c|c|c|c|c|c|c|c|}
\hline & & I_ktpv & I_ktpvy & I_gdpv & orptaxgdp & rel_pit & rirl & etcr & epl & crpriv & imcap & smturn & og \\
\hline log real capital stock & I_ktpv & 1.00 & 0.47 & 0.91 & 0.27 & -0.64 & -0.48 & -0.87 & -0.36 & 0.79 & 0.52 & 0.50 & 0.10 \\
\hline $\begin{array}{l}\text { log (real capital stock / } \\
\text { real output) }\end{array}$ & I_ktpwy & 0.47 & 1.00 & 0.07 & -0.23 & -0.29 & 0.10 & -0.30 & -0.28 & 0.49 & -0.04 & 0.05 & -0.27 \\
\hline log real output & I_gdpv & 0.91 & 0.07 & 1.00 & 0.42 & -0.59 & -0.59 & -0.85 & -0.28 & 0.67 & 0.60 & 0.54 & 0.23 \\
\hline corporate taxes/GDP & corptaxgdp & 0.27 & -0.23 & 0.42 & 1.00 & -0.39 & -0.52 & -0.31 & -0.07 & 0.09 & 0.32 & 0.23 & 0.23 \\
\hline $\begin{array}{l}\text { log relative prices of } \\
\text { investment }\end{array}$ & I_rel_pit & -0.64 & -0.29 & -0.59 & -0.39 & 1.00 & 0.40 & 0.60 & 0.09 & -0.41 & -0.38 & -0.37 & 0.01 \\
\hline $\begin{array}{l}\text { long-term real interest } \\
\text { rate }\end{array}$ & rirl & -0.48 & 0.10 & -0.59 & .52 & 0.40 & 1.00 & 0.49 & 0.16 & -0.23 & -0.43 & -0.42 & -0.13 \\
\hline ETCR & etcr & -0.87 & -0.30 & -0.85 & -0.31 & 0.60 & 0.49 & 1.00 & 0.35 & -0.61 & -0.50 & -0.47 & -0.09 \\
\hline EPL & epl & -0.36 & -0.28 & -0.28 & -0.07 & 0.09 & 0.16 & 0.35 & 1.00 & -0.24 & -0.24 & -0.29 & 0.04 \\
\hline private credit / GDP & crpriv & 0.79 & 0.49 & 0.67 & 0.09 & -0.41 & -0.23 & -0.61 & -0.24 & 1.00 & 0.34 & 0.34 & 0.10 \\
\hline $\begin{array}{l}\text { stock market } \\
\text { capitialisation }\end{array}$ & smcap & 0.52 & -0.04 & 0.60 & 0.32 & -0.38 & -0.43 & -0.50 & -0.24 & 0.34 & 1.00 & 0.82 & 0.19 \\
\hline stock mark & smturn & 0.50 & 0.05 & 0.54 & 0.23 & -0.37 & -0.42 & -0.47 & -0.29 & 0.34 & 0.82 & 1.00 & 0.10 \\
\hline output gap & og & 0.10 & -0.27 & 0.23 & 0.23 & 0.01 & -0.13 & -0.09 & 0.04 & 0.10 & 0.19 & 0.10 & 1.00 \\
\hline
\end{tabular}

Note: Cells in dark grey show correlation coefficients between series purged of country fixed effects. White cells report correlation coefficients between series purged of both country and year fixed effects.

Panel unit root tests are carried out to investigate the order of integration of the variables used in the empirical analysis. The Im-Pesaran-Shin test (2003) (IPS) panel unit root test is applied to the series used in the regression analysis. The IPS test allows for heterogeneity across countries in the autoregressive coefficient and the lag length used for individual countries. It tests the null hypothesis of a unit root against the alternative of the absence of a unit root. A model with a trend and a constant and a model with only a constant are used.

The following patterns emerge from the IPS test for 32 OECD countries for the period of 1985 to 2013 (Table 5). First, the tests show that the majority of the variables are integrated of order 1: they have a stochastic and/or a deterministic trend in levels. Second, the output gap variable has no unit root, which comes as no surprise. Finally, the IPS test indicates the absence of a unit root for all first- and seconddifferenced variables. 
Table 5. Im-Pesaran-Shin (IPS) panel unit root tests

32 OECD countries (MEX, CHL excluded), 1985-2013

\begin{tabular}{l|cc|cc|cc|} 
& \multicolumn{2}{|c|}{ level } & \multicolumn{2}{c|}{ 1st diff } & \multicolumn{2}{c|}{ 2nd diff } \\
& $\mathrm{c}$ & $\mathrm{c}+\mathrm{t}$ & $\mathrm{c}$ & $\mathrm{c}+\mathrm{t}$ & $\mathrm{c}$ & $\mathrm{c}+\mathrm{t}$ \\
\hline log real capital stock & 0.000 & 0.870 & 0.004 & 0.043 & 0.000 & 0.000 \\
log (real capital stock / real output) & 0.163 & 0.904 & 0.000 & 0.003 & 0.000 & 0.000 \\
log real output & 0.674 & 0.921 & 0.000 & 0.022 & 0.000 & 0.000 \\
corporate taxes/GDP & 0.004 & 0.183 & 0.000 & 0.000 & 0.000 & 0.000 \\
log relative prices of investment & 0.009 & 0.212 & 0.000 & 0.000 & 0.000 & 0.000 \\
long-term real interest rate & 0.355 & 0.030 & 0.000 & 0.000 & 0.000 & 0.000 \\
ETCR & 0.000 & 0.995 & 0.000 & 0.000 & 0.000 & 0.000 \\
EPL & 0.023 & 0.553 & 0.000 & 0.000 & 0.000 & 0.000 \\
private credit / GDP & 0.995 & 0.642 & 0.000 & 0.000 & 0.000 & 0.000 \\
stock market capitialisation & 0.108 & 0.551 & 0.000 & 0.000 & 0.000 & 0.000 \\
stock market turnover & 0.002 & 0.335 & 0.000 & 0.000 & 0.000 & 0.000 \\
output gap & 0.000 & 0.000 & 0.000 & 0.000 & 0.000 & 0.000
\end{tabular}

Source: OECD calculations

\subsection{Estimation methods}

Given the non-stationary nature of the data, cointegration techniques are needed to estimate the level relationships linking the capital stock with its long-term drivers. If the variables are not related through a cointegrating vector, the estimated level equations may be spurious.

The long-term coefficients are estimated on the basis of the Dynamic OLS (DOLS) estimator. Over the standard OLS estimator, it has the advantage that it corrects for the possible endogeneity of the regressors and autocorrelation in the residuals by incorporating leads and lags of the regressors in first differences (Stock and Watson, 1993):

$$
Y_{j, t}=\beta_{0}+\sum_{i=1}^{n} \beta_{n} X_{j, i, t}+\sum_{i=1}^{n} \sum_{l=-k_{1}}^{k_{2}} \gamma_{i, l} \Delta X_{j, i, t-l}+\varepsilon_{t}
$$

where $Y_{t}$ is the capital stock and $\bar{X}$ is the vector of capital stock drivers. j stands for individual countries, $\mathrm{i}$ for the regressors, $\mathrm{l}$ for the lags and leads and $\mathrm{k} 1$ and $\mathrm{k} 2$ represent respectively the maximum lags and leads. Equation (16) is estimated using country and time fixed effects.

Whether or not the variables of interest are cointegrated can be tested in two ways. First, the residuals obtained from the long-term relationship $\left(\varepsilon_{t}\right)$ can be used to estimate the error correction model in the second stage. Weak evidence for the presence of cointegration is if the error correction term in this second stage is statistically significant and has a negative sign. This implies an error correction mechanism to be in place. A second and more formal test of cointegration is when the estimated residuals from the long-term relationship are tested for the presence of a unit root. The rejection of the null hypothesis of a unit root can be interpreted in favour of cointegration, in the spirit of the Engle and Granger residual-based cointegration approach. Here we use Kao's residual-based panel cointegration tests (Kao 1999), which, along with equation (1), allows for country-specific intercepts but imposes homogenous coefficients.

Our modelling framework relies on a two-stage error correction model. Modelling investment could also be based on a single-equation error correction model, along the lines of equation (17): 


$$
\Delta K_{t}=c+\gamma K_{t-1}+\sum_{i=1}^{n} \beta_{i} X_{i, t-1}+\mu \Delta K_{t-1}+\sum_{i=1}^{n} \delta_{i} \Delta X_{i, t}+\varepsilon_{t}
$$

where $\gamma k_{t-1}+\sum_{i=1}^{n} \beta_{i} x_{i, t-1}$ gives the long-run relationship including the $n$ long-term covariates, $\sum_{i=1}^{n} \delta_{i} \Delta x_{i, t}$ are the dynamic terms of the long-run variables such as real output, UCC and ETCR.

Nevertheless, the two-stage approach provides more flexibility for our purpose compared to a singleequation error correction model. Importantly, the two-stage approach allows for putting country and year fixed effects in the long-run relationship and for including only country fixed effects in the short-term dynamics. In the single-equation approach, one can put either only country fixed effects or country \& year fixed effects both in the long-run and short-run relationship. To illustrate the lack of flexibility of the single-step approach is when one wants to use a measure of common trend (capturing for instance global uncertainty in the short-run dynamics). It can be used only without year fixed effects, but this would mean that year fixed effects would not be included in the long-run relationship.

\section{Estimation results}

The standard investment model works fine: only the real interest rate is found weakly related to the capital stock. We first estimate an investment model which links the level of capital stock to the level of output and the components of the user cost (long-term real interest rates, corporate taxes and relative investment prices). All regressions include the output gap to control for cyclical fluctuations in the dependent and independent variables. Output has a positive and almost unity correlation with the capital stock. Long-term real interest rates, the corporate taxes-to-GDP ratio and the relative investment price variable bear the expected negative sign. ${ }^{9}$ However, the corporate tax variable and to some extend the real interest rate variable are not always statistically significant. To be fully consistent with theory, we keep all three components of the user cost of capital in the specifications augmented by structural policy indicators.

\subsection{Product market regulation}

Product market regulation, measured by the OECD's ETCR indicator, shows a fairly robust negative relationship with the capital stock series. We proceed step by step by augmenting the standard investment model by structural policy indicators. We first add the ETCR indicator. It has a strong negative correlation with the capital stock. Estimation results reported in Table 6a suggest that on average, a unit change in the ETCR indicator is associated with an increase of somewhere between $4 \%$ and $5 \%$ in the capital stock (columns 2 to 5). The relationship holds broadly if the capital stock is regressed on the log-level rather than the level of the ETCR indicator (Table 6a, 6b and 6c). The results are also fairly robust if the sample is reduced to the pre-crisis period (1985 to 2006 from 1985 to 2013, columns 3 and 4) or if the country coverage is reduced (column 5). The regressions are also carried out using the capital stock-to-GDP ratio (the real output variable is dropped as a regressor). The results are robust when using ETCR in levels (columns 7 to 10) but the standard errors are very large for log-level ETCR indicator (column 6).

\subsection{Labour and product market regulations}

The employment protection legislation (EPL) indicator has a strong and quantitatively important negative relationship to the capital stock (Table $6 \mathrm{~b}$ ). This is an interesting result given the mixed evidence emerging from the firm-level studies mentioned earlier (Autor et al., 2007 and Cingano et al., 2010 and 2015). We carried out a number of robustness checks. First, we used both the level and log-level of EPL. Second, we reduced our country coverage. Third, we employed the capital stock-to-labour ratio used in the above mentioned studies as dependent variable. Finally, we also ran regressions including only EPL as explanatory variables (but keeping the country and year fixed effects in the regressions), given that the

\footnotetext{
${ }^{9}$ Results for the baseline model are not reported here but are available upon request. All regressions include country and year fixed effects.
} 
micro studies do not tend to include other policy- and investment-specific controls. The results are very robust to these sensitivity checks: the coefficient on EPL is negative and is precisely estimated.

Other labour market indicators are also looked at. These are spending on active labour market polices, the tax wedge and the gross unemployment benefit replacement rate. ALMP is usually statistically significant (columns 2 and 4 in Table 6b). Tax wedge and the gross unemployment benefit replacement rate either have large standard errors or have a counterintuitive positive sign (these results are not reported here). Therefore, these variables are dropped from further analysis.

\subsection{Financial development, labour and product market regulations}

Access to finance is thought to be important for investment decision: a relatively easy availability to external funding is likely to increase investment. Three measures of external finance are used in this paper. One that approximates access to bank finance: the private credit-to-GDP ratio. Two other indicators used here measure market finance: stock market capitalisation over GDP; and stock market turnover over GDP. These finance indicators are added one-by-one to the specifications including product and labour market regulations. There is a fairly sizeable strong positive connection between capital stock and private credit as a share of GDP: a one percent increase in the private credit-to-GDP ratio is accompanied by a rise of roughly 0.2 percent in the capital stock (column 1 in Table 6c).

It is more difficult to establish a statistically significant correlation between stock market capitalisation and turnover on the one hand and the capital stock on the other: the estimation results shed light on a small but positive relationship between the stock market variables and the capital stock. Yet this relationship becomes unstable to alternative model specifications, especially when these variables are used in levels (percentage points) rather than in log levels and when the capital stock-to-output ratio is used as the dependent variable.

The question one may want to ask now is what happens to the labour and product market regulation indicators. EPL, our labour market regulation indicator, comes across as an extremely robust variable in this new set of regressions. The inclusion of financial development does not change its significance, sign or magnitude: it has a negative sign and is significant at the $5 \%$ level in all cases. The size of the coefficient estimate is about 0.3 , as before. The ETCR indicator, capturing product market regulation, also bears a strong negative relation to the capital stock, similarly to results reported in Tables $6 \mathrm{a}$ and $6 \mathrm{~b}$.

\subsection{Asymmetric effects}

Thus far, we have looked at simple linear relationships between the capital stock and structural policy indicators. Yet policies may bear a more complex relationship to investment. The relationship may be asymmetric to the direction of the change in policies, e.g. when policies are getting tighter or more competition friendly. Policies may amplify or attenuate each other's influence on the capital stock. They may have a non-linear relationship to the capital stock.

Table 7a reports results of the analysis on directional asymmetries in the policy variables. Testing the null hypothesis of no asymmetry against the alternative of an asymmetric effect indicates the absence of directional asymmetry for the ETCR and private credit-to-GDP ratio. By contrast, the null of no asymmetry can be systematically rejected if asymmetry depends on directional changes in the EPL indicator (Table 7a). The negative impact of ETCR and EPL on the capital stock is larger (and significant) if EPL is being increased, that is if employment protection legislation is becoming more stringent. At the same time, the positive correlation between private credit and the capital stock strengthens when EPL is being relaxed. But overall, these results are not robust when using the capital stock-to-output ratio (rather than the log real capital stock): the F- test cannot reject the null of parameter homogeneity (absence of 
asymmetric reaction). Also, the results for the private credit variable are sensitive to whether this variable is considered in levels or in log-levels.

\subsection{Smooth and threshold non-linear effects: policy effects depending on their own level}

Policies may be related to investment through a long-term non-linear relationship. Two types of a possible non-linear relationship are considered here. First, squared terms of the policy indicators are added to the regressions. The squared term, if significant, implies a smooth non-linear effect. The estimation results shed light on a smooth non-linear effect of EPL on the capital stock (Table 7b). Combining the coefficient estimates on the linear and squared term indicates that the negative correlation between EPL and the capital stock becomes smaller at lower levels of EPL. In policy terms, this implies that the payoff of relaxing employment protection legislation is larger if the initial level of protection is high.

Threshold regressions reported in Table 7c (columns 3 and 4) corroborate these results to some extent: the negative coefficient estimate on the EPL indicator becomes non-significant if EPL is below a certain level when using real capital stock. But this relationship breaks down for the capital stock/output is the dependent variable and when country averages of EPL are used as the threshold variable.

The empirical results show the absence of a smooth non-linear effect of ETCR and private credit: in alternative estimation setups, the coefficient estimates of these variables are estimated with high standard errors. Threshold regressions are also not very robust for these variables. For ETCR, whether the negative effect is larger or smaller when ETCR is high or low can change depending on model specification (Table $7 b) .{ }^{10}$

\subsection{Threshold non-linear effects: policy effects depending on the level of other policies}

Let us now turn to the threshold regressions in which the effects ETCR and EPL depend on the level of the PMR sub-indicators and the World Bank's doing business and quality of institutions indicators, i.e. when the time-invariant variables are used as threshold variable. Generally speaking, ETCR appears to exhibit non-linear behaviour in function of the level of the headline PMR indicator: at higher levels of the overall PMR and its three main sub-components (state control, barriers to entrepreneurship; and barriers to trade and investment), the negative impact of ETCR on both measures of the capital stock are substantially larger (Table 7c). This finding is in line with the threshold results when the country average of the ETCR indicator is used as a threshold variable. To illustrate the economic importance of this effect, if barriers to entrepreneurship is higher than 1.8, a one unit increase in ETCR will result in a 3\% decrease in real capital stock and a 6\% drop in the capital-to-output ratio. The threshold value of 1.8 is below the sample average of 2.06 (reported in Table 3b). If this particular PMR sub-component is lower than 1.8, there is then no significant correlation between ETCR and the capital stock. There is a significant relationship for capital stock/output but the decrease is roughly two-third lower than in the higher regime.

The estimated threshold effects are very similar for EPL: its negative impact on capital is substantially higher if PMR is above the estimated threshold. The threshold values are surprisingly close to those estimated for ETCR. Also, these effects are in line with the results when country averages of ETCR are used as a threshold variable.

It is difficult to identify reasonably robust non-linear relationships when the doing business indicators are used as threshold variables. For the various doing business indicators, whether or not the estimated effect in a particular non-linear regime is significant and whether the impact of ETCR and EPL is higher (lower)

10 Threshold results for private credit are not reported: the results are very sensitive to changes in modelling parameters. 
when the particular doing business indicator is above (below) the estimated tipping point depends on how capital stock is measured. In addition, similar measures, such as the cost and time of insolvency procedures yield contradicting results.

Finally, a straightforward pattern emerges for institutions: better rule of law and a higher quality legal system dampens the negative ETCR and EPL impacts. When the rule of law and the quality of the legal system are below the estimated threshold values, EPL exhibits a strong negative correlation with the capital stock. The correlation turns positive above the threshold values. ETCR has a negative effect on the capital stock-to-output ratio if the rule of law and the legal system do not attain a given level of quality. The estimated threshold effects are typically above the sample average

\subsection{Policy interactions}

Looking at interactions with time-invariant structural characteristics provides useful insights on policy complementarities. The interactions for EPL and ETCR for which country averages of ETCR and EPL are interacted with time-varying EPL and ETCR series yield a fairly clear picture. The interaction terms are always negative. The base effects also tend to be strongly negative. This implies that countries with high level of ETCR will suffer from an overall higher negative ETCR impact. By the same token, countries with more stringent EPL will observe a more negative EPL impact. The combined effects of policies go in a similar direction. Higher ETCR exacerbates the negative impact of EPL. Also, higher EPL increases the negative ETCR impact.

Let us now turn to the interactions with the PMR indicator and its sub-components. The results are not very different from the average EPL and ETCR outcomes. A higher overall PMR indicator and higher levels of state control, barriers to entrepreneurship and larger barriers to trade and investment are all associated with a more negative ETCR and EPL impact on the capital stock.

The general business environment, captured through the World Bank's doing business indicators do tend to provide with the fuzzy results observed for threshold regressions. One can observe both negative and positive interaction effects, with statistically non-significant results in a number of cases.

When it comes to institutions, they no doubt do matter for ETCR and EPL. Higher rule of law and better legal systems have consistently positive (and statistically significant) interaction terms. This means that countries with better institutions will face less negative ETCR and EPL impacts on their stock of capital. By contrast, in a country with weak rule of law, the negative ETCR and EPL effects will be larger (Table 8). These results are very close to those obtained for threshold regressions. Nevertheless, they differ in that the combination of the base and marginal effects may result in positive ETCR and EPL impacts if institutions are of high quality and that the negative overall ETCR and EPL effects can be more negative with very low-quality institutions.

\subsection{Policies, institutions and the speed of adjustment}

It can be tested whether policies and institutions have an influence on the speed of adjustment towards the long-run equilibrium. However, in practice and for our capital stock estimates, only two policies appear to affect the error correction term. They are the EPL and barriers to trade and investment. This suggests that countries with stricter EPL will experience a slower adjustment to the long-term equilibrium. But this also means that any reform that aims a lower EPL will speed up the convergence to the long-run steady state. By contrast, the marginal interaction term on barriers to trade and investment is negative. As the overall error correction term becomes more negative (larger in absolute terms), this means that countries with higher barriers and higher costs will reduce the gap to the long-run equilibrium at a higher speed. This could mean that the impact of bad policies will materialise quicker. 
Table 6a. Product market regulation, 1985-2013

dependent variable

\begin{tabular}{|c|c|c|c|c|c|c|c|c|c|c|}
\hline & \multicolumn{5}{|c|}{ log real capital stock } & \multicolumn{5}{|c|}{$\log$ (real capital stock / real output) } \\
\hline & (1) & (2) & (3) & (4) & \multirow{3}{*}{$\begin{array}{c}\text { (5) } \\
\text { core OECD } \\
1985-2013 \\
\end{array}$} & (6) & (7) & (8) & (9) & \multirow{2}{*}{$\begin{array}{c}(10) \\
\text { core OECD }\end{array}$} \\
\hline & \multicolumn{4}{|c|}{ most observations possible } & & \multicolumn{4}{|c|}{ most observations possible } & \\
\hline & 1985 & -2013 & $1985-2006$ & 1990-2006 & & 1985 & -2013 & 1985-200 & $1990-2006$ & $1985-2013$ \\
\hline constant & $2.724^{* *}$ & $2.226^{*}$ & 0.045 & 2.132 & 0.736 & $0.901^{* *}$ & $0.956 * *$ & $0.959 * *$ & $0.965^{* *}$ & $0.993 * *$ \\
\hline real output & $0.938 * *$ & $0.957 * *$ & $1.038^{* *}$ & $0.961 * *$ & $1.013^{* *}$ & & & & & \\
\hline ice of investment & $-0.266 * *$ & $-0.317 * *$ & $-0.472 * *$ & $-0.395 * *$ & $-0.448 * *$ & $-0.262 * *$ & $-0.377 * *$ & $-0.627^{* *}$ & $-0.573^{* *}$ & $-0.429 * *$ \\
\hline erest rate & $-0.005 * *$ & $-0.005 * *$ & $-0.006 * *$ & -0.004 & $-0.005^{* *}$ & 0.002 & 0.002 & -0.001 & 0.003 & 0.001 \\
\hline log corporate tax to-GDP-ratio & 0.005 & & & & & $-0.098 * *$ & & & & \\
\hline corporate tax to-GDP-ratio & & -0.002 & $-0.010^{* *}$ & -0.004 & -0.004 & & $-0.024 * *$ & $-0.034 * *$ & $-0.023 * *$ & $-0.025 * *$ \\
\hline $\log$ ETCR & $-0.073 * *$ & & & & & -0.039 & & & & \\
\hline ETCR & & $-0.035 * *$ & $-0.037 * *$ & $-0.044 * *$ & $-0.051 * *$ & & $-0.035 * *$ & $-0.024 * *$ & $-0.044 * *$ & $-0.048 * *$ \\
\hline cointegr & 0.001 & 0.001 & 0.011 & 0.005 & 0.002 & 0.031 & 0.035 & 0.193 & 0.099 & 0.054 \\
\hline error & $-0.100 * *$ & $-0.099 * *$ & $-0.094 * *$ & $-0.113 * *$ & $-0.093 * *$ & $-0.033 * *$ & $-0.026 * *$ & $-0.019 * *$ & $-0.044^{* *}$ & $-0.025^{* *}$ \\
\hline No. observ & 705 & 705 & 533 & 426 & 633 & 705 & 705 & 533 & 426 & 633 \\
\hline No. countries & 32 & 32 & 32 & 32 & 25 & 32 & 32 & 32 & 32 & 25 \\
\hline
\end{tabular}

Note: * and ** denote statistical significance at the $10 \%$ and $5 \%$ levels, respectively, based on robust standard errors. Country and year fixed effects are included in all regressions. "l_” denotes variables taken in natural logs.

Table 6b. Labour and product regulations, 1985-2013

\begin{tabular}{|c|c|c|c|c|c|c|c|c|c|c|c|c|}
\hline & & $\log$ real ca & pital stock & & $\log (\mathrm{re}$ & $\begin{array}{l}\text { depender } \\
\text { I capital s }\end{array}$ & $\begin{array}{l}\text { t variable } \\
\text { ock / rea }\end{array}$ & output) & $\log ($ rea & capital st & ock / emp & oyment) \\
\hline & (1) & (2) & (3) & (4) & (5) & (6) & (7) & (8) & (9) & (10) & (11) & (12) \\
\hline constant & $11.031^{* *}$ & $10.806^{\star *}$ & $11.538^{* *}$ & $9.108^{\star \star}$ & $1.153^{\star *}$ & $0.952^{\star *}$ & $1.207^{\star *}$ & $0.977^{\star *}$ & $11.765^{\star *}$ & $12.499^{* *}$ & $11.264^{\star *}$ & $11.811^{\star *}$ \\
\hline real output & $0.646^{\star \star}$ & $0.645^{\star \star}$ & $0.631^{\star \star}$ & $0.708^{\star \star}$ & & & & & 0.042 & 0.014 & 0.063 & 0.038 \\
\hline relative price of investment & $-0.57^{\star \star}$ & $-0.337^{\star \star}$ & $-0.607^{\star \star}$ & $-0.434^{\star \star}$ & $-0.594^{\star *}$ & $-0.447^{\star \star}$ & $-0.69^{\star *}$ & $-0.561^{\star *}$ & $-0.583^{\star \star}$ & $-0.466^{\star \star}$ & $-0.601^{\star *}$ & $-0.538^{\star *}$ \\
\hline long-term real interest rate & $-0.007^{\star \star}$ & $-0.007^{\star \star}$ & $-0.006^{\star \star}$ & -0.005 & 0.001 & 0.0001 & 0.002 & 0.003 & -0.001 & -0.002 & -0.001 & -0.001 \\
\hline log corporate tax to-GDP-ratio & $-0.03^{\star}$ & -0.019 & & & $-0.111^{\star *}$ & $-0.086^{\star \star}$ & & & -0.012 & -0.005 & & \\
\hline $\log$ ETCR & $-0.098^{\star \star}$ & $-0.096^{\star \star}$ & & & $-0.127^{\star *}$ & $-0.128^{\star \star}$ & & & $-0.072^{\star \star}$ & $-0.087^{\star \star}$ & & \\
\hline log EPL permanent contracts & $-0.232^{\star *}$ & & & & $-0.206^{\star \star}$ & & & & $-0.128^{\star *}$ & & & \\
\hline $\log$ ALMP & & 0.014 & & & & 0.012 & & & & -0.017 & & \\
\hline corporate tax to-GDP-ratio & & & $-0.006^{*}$ & -0.003 & & & $-0.026^{\star \star}$ & $-0.018^{\star *}$ & & & -0.003 & -0.001 \\
\hline ETCR & & & $-0.031^{\star \star}$ & $-0.043^{\star \star}$ & & & $-0.054^{\star \star}$ & $-0.056^{\star *}$ & & & $-0.03^{\star \star}$ & $-0.037^{\star *}$ \\
\hline EPL permantent contracts & & & $-0.118^{\star \star}$ & & & & $-0.089^{\star *}$ & & & & $-0.066^{\star \star}$ & \\
\hline ALMP & & & & 0.0001 & & & & 0.0003 & & & & -0.0004 \\
\hline cointegration: Kao $\mathrm{H} 0=$ no coint & 0.0056 & 0.0131 & 0.0072 & 0.0193 & 0.0713 & 0.0895 & 0.0883 & 0.1264 & 0.0486 & 0.1011 & 0.0769 & 0.2753 \\
\hline error correction term & $-0.036^{\star *}$ & $-0.066^{\star \star}$ & $-0.036^{\star \star}$ & $-0.048^{\star \star}$ & 0.001 & -0.012 & 0.008 & -0.005 & $-0.065^{\star *}$ & $-0.061^{\star *}$ & $-0.064^{\star *}$ & $-0.065^{\star \star}$ \\
\hline No. observations & 467 & 460 & 467 & 460 & 467 & 460 & 467 & 460 & 467 & 460 & 467 & 460 \\
\hline No. countries & 27 & 27 & 27 & 27 & 27 & 27 & 27 & 27 & 27 & 27 & 27 & 27 \\
\hline
\end{tabular}

Note: as for Table $6 a$. 
Table 6c. Financial development \& labour and product regulations, 1985-2013

\begin{tabular}{|c|c|c|c|c|c|c|c|c|c|c|c|c|}
\hline & \multicolumn{12}{|c|}{ dependent variable } \\
\hline & \multicolumn{6}{|c|}{ log real capital stock } & \multicolumn{6}{|c|}{ log (real capital stock / real output) } \\
\hline & (1) & (2) & (3) & (4) & (5) & (6) & (7) & (8) & (9) & (10) & (11) & (12) \\
\hline constant & $16.461^{\star *}$ & $11.541^{\star \star}$ & $11.433^{\star \star}$ & $16.222^{\star \star}$ & $11.949 * *$ & $12.323^{\star *}$ & $0.469^{\star *}$ & $1.078^{\star \star}$ & $1.023^{\star \star}$ & $0.998^{\star \star}$ & $1.214^{\star \star}$ & $1.182^{\star *}$ \\
\hline real output & $0.415^{\star \star}$ & $0.625^{\star \star}$ & $0.629^{\star *}$ & $0.452^{\star \star}$ & $0.616^{\star \star}$ & $0.603^{\star \star}$ & & & & & & \\
\hline relative price of investment & $-0.338^{\star *}$ & $-0.562^{\star *}$ & $-0.561^{\star *}$ & $-0.409^{* *}$ & $-0.602^{\star *}$ & $-0.6^{\star *}$ & $-0.437^{\star *}$ & $-0.585^{\star *}$ & $-0.612^{\star *}$ & $-0.521^{\star *}$ & $-0.708^{* *}$ & $-0.694^{\star *}$ \\
\hline long-term real interest rate & -0.004 & $-0.006^{\star *}$ & $-0.006^{\star *}$ & $-0.006^{* *}$ & $-0.006^{\star *}$ & $-0.006^{\star \star}$ & 0.001 & 0.002 & 0.003 & 0.0002 & 0.003 & 0.003 \\
\hline log corporate tax to-GDP-ratio & -0.008 & $-0.038^{* *}$ & $-0.035^{\star *}$ & & & & $-0.061^{\star *}$ & $-0.118^{* *}$ & $-0.108^{\star *}$ & & & \\
\hline $\log$ ETCR & $-0.057^{\star *}$ & $-0.097^{\star *}$ & $-0.102^{\star \star}$ & & & & $-0.119^{\star \star}$ & $-0.129^{* *}$ & $-0.141^{\star *}$ & & & \\
\hline log EPL permanent contracts & $-0.227^{\star *}$ & $-0.182^{\star *}$ & $-0.183^{\star \star}$ & & & & $-0.22^{\star \star}$ & $-0.149^{* *}$ & $-0.143^{\star *}$ & & & \\
\hline corporate tax to-GDP-ratio & & & & -0.002 & $-0.006^{*}$ & $-0.006^{*}$ & & & & $-0.019 * *$ & $-0.027^{\star \star}$ & $-0.025^{\star *}$ \\
\hline ETCR & & & & $-0.026^{\star *}$ & $-0.029 * *$ & $-0.031^{* *}$ & & & & $-0.054^{* *}$ & $-0.041^{\star \star}$ & $-0.055^{\star *}$ \\
\hline EPL permantent contracts & & & & $-0.104^{\star \star}$ & $-0.115^{\star *}$ & $-0.114^{\star \star}$ & & & & $-0.072^{\star \star}$ & $-0.1^{\star \star}$ & $-0.079^{* *}$ \\
\hline log private credit-to-GDP ratio & $0.186^{\star \star}$ & & & & & & $0.139 * \star$ & & & & & \\
\hline log stock market capitalisation (\% of GDP) & & $0.012^{\star *}$ & & & & & & 0.012 & & & & \\
\hline log stock market return (\% GDP) & & & $0.011^{\star}$ & & & & & & $0.022^{\star \star}$ & & & \\
\hline private credit-to-GDP ratio & & & & $0.002^{\star \star}$ & & & & & & $0.001^{\star \star}$ & & \\
\hline stock market capitalisation (\% of GDP) & & & & & -0.0001 & & & & & & $-0.0004^{\star *}$ & \\
\hline stock market return (\% GDP) & & & & & & -0.0001 & & & & & & -0.0001 \\
\hline cointegration: $\mathrm{Kao} \mathrm{HO}=$ no coint & 0.0024 & 0.0058 & 0.0048 & 0.0016 & 0.0024 & 0.0045 & 0.0261 & 0.0725 & 0.0713 & 0.0259 & 0.0633 & 0.0904 \\
\hline error correction term & $-0.042^{\star \star}$ & $-0.036 * *$ & $-0.035^{\star \star}$ & $-0.054^{\star *}$ & $-0.028^{\star *}$ & $-0.035^{\star *}$ & $-0.05^{\star \star}$ & -0.001 & 0.002 & $-0.052^{* *}$ & 0.003 & 0.004 \\
\hline No. observations & 464 & 453 & 438 & 464 & 453 & 438 & 464 & 453 & 438 & 464 & 453 & 438 \\
\hline No. countries & 27 & 27 & 27 & 27 & 27 & 27 & 27 & 27 & 27 & 27 & 27 & 27 \\
\hline
\end{tabular}

Note: as for Table 6a.

Table 7a. Asymmetric effects, 1985-2013

Asymmetric effects depend on the directional change in the EPL indicator

dependent variable

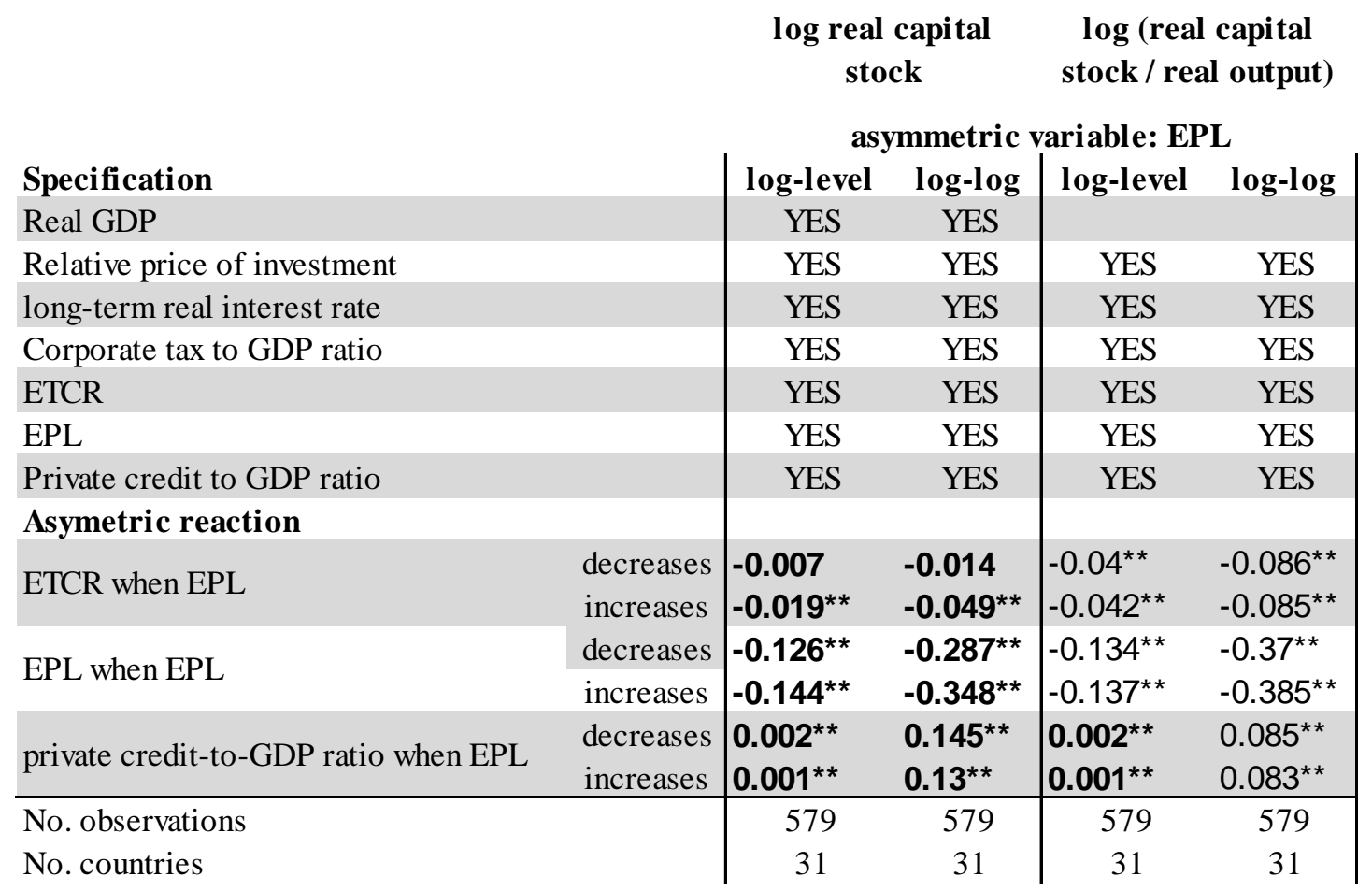

Note: as for Table 6a. Each pair of coefficient (decrease \& increase) is estimated in separate equations including the controls listed in the table. Bold figures indicate that the F-test rejects the null hypothesis of parameter homogeneity and that the Kao test of cointegration rejects the null hypothesis of no cointegration and the error correction terms is negative and statistically significant. 
Table 7b. Smooth non-linear effects, 1985-2013

\begin{tabular}{|c|c|c|c|c|c|c|c|c|c|c|}
\hline \multirow[b]{3}{*}{ real output } & \multicolumn{5}{|c|}{$\log$ real capital stock } & \multicolumn{5}{|c|}{$\log$ (real capital stock / real output) } \\
\hline & (1) & $(2)$ & (3) & (4) & $(5)$ & (6) & (7) & (8) & (9) & $(10)$ \\
\hline & $0.741^{* *}$ & $0.714^{* *}$ & $0.641^{* *}$ & $0.651^{* *}$ & $0.624 * *$ & & & & & \\
\hline relative price of investment & $-0.372^{* *}$ & $-0.232 * *$ & $-0.364 * *$ & $-0.256^{* *}$ & $-0.352^{* *}$ & $-0.654 * *$ & $-0.5^{* *}$ & $-0.699 * *$ & $-0.557 * *$ & $-0.641 * *$ \\
\hline long-term real interest rate & $-0.005^{* *}$ & $-0.004 * *$ & $-0.005^{* *}$ & $-0.005 * *$ & $-0.005^{* *}$ & $0.005^{* *}$ & $0.006^{* *}$ & 0.003 & $0.004^{*}$ & 0.002 \\
\hline corporate tax-to-GDP ratio & -0.001 & -0.0002 & -0.003 & -0.004 & -0.004 & $-0.027 * *$ & $-0.025^{* *}$ & $-0.03^{* *}$ & $-0.03 * *$ & $-0.029 * *$ \\
\hline ETCR & -0.001 & -0.01 & -0.004 & $-0.019 * *$ & $-0.015^{* *}$ & $0.042^{*}$ & $-0.025^{* *}$ & 0.026 & $-0.041^{* *}$ & $-0.039 * *$ \\
\hline EPL & $-0.152 * *$ & $0.343^{* *}$ & $-0.151 * *$ & $0.184^{* *}$ & $-0.161^{* *}$ & $-0.141 * *$ & $0.373^{* *}$ & $-0.138^{* *}$ & $0.195^{* *}$ & $-0.156^{* *}$ \\
\hline private credit to GDP ratio & & & $0.001^{* *}$ & $0.001^{* *}$ & $0.002 * *$ & & & $0.001^{* *}$ & $0.001^{* *}$ & 0.001 \\
\hline \multicolumn{11}{|l|}{ squared effects } \\
\hline ETCR $\wedge 2$ & -0.002 & & -0.002 & & & $-0.01 * *$ & & $-0.01 * *$ & & \\
\hline $\mathrm{EPL} \wedge 2$ & & $-0.091 * *$ & & $-0.062 * *$ & & & $-0.096 * *$ & & $-0.063 * *$ & \\
\hline private credit-to-GDP ratio $\wedge 2$ & & & & & $-2 \mathrm{E}-06$ & & & & & $3 \mathrm{E}-07$ \\
\hline cointegration: Kao $\mathrm{H} 0=$ no coint & 0.0008 & 0.0003 & 0.0001 & 0 & 0.0001 & 0.0282 & 0.0099 & 0.0102 & 0.0039 & 0.0102 \\
\hline error correction term & $-0.093^{* *}$ & $-0.109 * *$ & $-0.106 * *$ & $-0.117 * *$ & $-0.106 * *$ & $-0.019 *$ & $-0.036 * *$ & $-0.05^{* *}$ & $-0.057 * *$ & $-0.053 * *$ \\
\hline No. observations & 600 & 600 & 579 & 579 & 579 & 600 & 600 & 579 & 579 & 579 \\
\hline No. countries & 31 & 31 & 31 & 31 & 31 & 31 & 31 & 31 & 31 & 31 \\
\hline
\end{tabular}

Note: as for Table 6a.

Table 7c. Threshold non-linear effects, 1985-2013

\begin{tabular}{|c|c|c|c|c|c|c|c|c|c|c|}
\hline \multirow{4}{*}{$\begin{array}{l}\text { dependent variable } \\
\text { non-linear variable }\end{array}$} & \multicolumn{5}{|c|}{ log real capital stock } & \multicolumn{5}{|c|}{ log (real capital stock / real output) } \\
\hline & \multicolumn{3}{|c|}{ ETCR } & \multicolumn{2}{|r|}{ EPL } & \multicolumn{3}{|c|}{ ETCR } & \multicolumn{2}{|r|}{ EPL } \\
\hline & \multicolumn{3}{|c|}{$\begin{array}{l}\text { when threshold } \\
\text { variable is }\end{array}$} & \multirow{2}{*}{$\begin{array}{c}\text { Threshold } \\
\text { value }\end{array}$} & \multirow{2}{*}{$\begin{array}{l}\text { when threshold } \\
\text { variable is } \\
\text { d below above } \\
\text { the threshold }\end{array}$} & \multirow[b]{2}{*}{$\begin{array}{c}\text { Thresholc } \\
\text { value }\end{array}$} & \multicolumn{2}{|c|}{$\begin{array}{l}\text { when threshold } \\
\text { variable is }\end{array}$} & \multirow[b]{2}{*}{$\begin{array}{c}\text { Threshold } \\
\text { value }\end{array}$} & $\begin{array}{l}\text { when threshold } \\
\text { variable is }\end{array}$ \\
\hline & $\begin{array}{c}\text { Threshold } \\
\text { value }\end{array}$ & $\begin{array}{l}\text { below } \\
\text { the thres }\end{array}$ & $\begin{array}{l}\text { above } \\
\text { hold value }\end{array}$ & & & & $\begin{array}{l}\text { below } \\
\text { the thres! }\end{array}$ & $\begin{array}{r}\text { above } \\
\text { shold value }\end{array}$ & & $\begin{array}{l}\text { below above } \\
\text { the threshold }\end{array}$ \\
\hline Threshold variable & & & & & & & & & & \\
\hline \multicolumn{11}{|c|}{ Product and labour market regulations } \\
\hline ETCR & 2.3 & $-0.042^{\star *}$ & $-0.026^{\star *}$ & 2.3 & $-0.169^{* \dagger}-0.148^{*}$ & 5.2 & $-0.029^{\star *}$ & $-0.041^{\star \star}$ & 5.2 & $-0.138^{\star \star}-0.167^{\star \star}$ \\
\hline EPL & 2.4 & $-0.044^{* *}$ & $-0.017^{* *}$ & 2.8 & $-0.023-0.076 *$ & 2.4 & $-0.071^{* *}$ & $-0.039 * \star$ & 2.4 & $-0.301^{\star \star}-0.246^{\star \star}$ \\
\hline ETCR average & 4.5 & -0.010 & $-0.03^{* \star}$ & 4.4 & $-0.124^{* t}-0.361^{*}$ & 4.4 & $-0.026^{\star *}$ & $-0.057^{\star \star}$ & 4.5 & $-0.164^{\star \star} 0.457^{\star \star}$ \\
\hline EPL average & 2.2 & $-0.047^{* *}$ & $-0.017^{* *}$ & 2.6 & $-0.023-0.193 *$ & 1.4 & 0.011 & $-0.038^{\star \star}$ & 2.6 & $-0.048-0.178^{\star \star}$ \\
\hline \multicolumn{11}{|l|}{ PMR \& sub-indicators } \\
\hline aggregate indicator & 1.8 & -0.011 & $-0.076^{\star \star}$ & 1.9 & $-0.123^{\star \prime}-0.44^{\star \star}$ & 1.9 & $-0.033^{\star *}$ & $-0.122^{\star \star}$ & 1.9 & $-0.116^{\star \star}-0.412^{\star \star}$ \\
\hline state control & 2.4 & -0.004 & $-0.034^{\star *}$ & 2.8 & $-0.143^{* t}-0.633^{*}$ & 2.4 & $-0.018^{\star *}$ & $-0.057 *$ & 2.9 & $-0.14^{* *}-0.83^{* *}$ \\
\hline barriers to entrepreneurship & 1.8 & -0.006 & $-0.031^{\star *}$ & 1.8 & $0.043-0.207 *$ & 1.8 & $-0.021^{\star *}$ & $-0.056^{\star \star}$ & 1.8 & $0.035-0.197 *$ \\
\hline barriers to trade and investment & 1.1 & $-0.016^{* *}$ & $-0.11^{* \star}$ & 0.4 & $0.095^{* *}-0.191 *$ & 1.1 & $-0.043^{\star *}$ & $-0.108^{\star \star}$ & 0.4 & $0.095^{\star \star}-0.186^{\star \star}$ \\
\hline \multicolumn{11}{|l|}{ Doing business } \\
\hline contract enforcement - cost & 14.4 & $-0.051^{\star *}$ & $-0.019^{* \star}$ & 15.0 & $-0.244^{* t}-0.125^{*}$ & 14.4 & $-0.092^{\star *}$ & $-0.04^{\star \star}$ & 24.2 & $-0.168 * 0.088$ \\
\hline contract enforcement - time & 395.0 & $-0.042^{\star \star}$ & $-0.018^{\star \star}$ & 397.0 & $-0.22^{\star *}-0.125^{*}$ & 395.0 & $-0.079^{\star *}$ & $-0.038^{\star \star}$ & 567.5 & $-0.164^{\star \star} 0.466^{* \star}$ \\
\hline insolvency costs & 6.8 & $-0.042^{\star \star}$ & $-0.013^{\star *}$ & 15.0 & $-0.168^{\star \star} 0.14^{\star \star}$ & 6.8 & $-0.067^{\star *}$ & $-0.035^{\star \star}$ & 15.4 & $-0.169^{\star \star} 0.264^{\star \star}$ \\
\hline insolvency time & 1.5 & -0.009 & $-0.035^{* *}$ & 1.2 & $0.018-0.202 *$ & 1.5 & $-0.026^{\star *}$ & $-0.059^{* *}$ & 2.3 & $-0.165^{\star \star} 0.463^{\star \star}$ \\
\hline insolvency recovery rate & 73.9 & $-0.029^{* *}$ & -0.012 & 86.5 & $-0.19^{* *} 0.035$ & 73.9 & $-0.053^{\star \star}$ & $-0.029^{\star \star}$ & 67.9 & $0.374^{\star \star}-0.169^{* \star}$ \\
\hline starting a business - cost & 6.8 & -0.002 & $-0.034^{\star *}$ & 1.1 & $0.084^{* *}-0.203^{*}$ & 6.8 & -0.010 & $-0.057^{\star *}$ & 5.5 & $0.057^{*}-0.208^{* \star}$ \\
\hline starting a business - time & 21.6 & $-0.036^{* *}$ & -0.006 & 13.2 & $-0.273^{* t}-0.127^{*}$ & 21.6 & $-0.061^{\star \star}$ & $-0.025^{\star \star}$ & 13.2 & $-0.297^{\star \star}-0.112^{\star \star}$ \\
\hline \multicolumn{11}{|l|}{ Institutions } \\
\hline rule of law & 1.5 & $-0.038^{* *}$ & -0.003 & 1.8 & $-0.203^{* \prime} 0.101^{* *}$ & 1.5 & $-0.063^{* *}$ & -0.012 & 1.8 & $-0.198^{\star \star} 0.099^{\star \star}$ \\
\hline legal system & 8.1 & $-0.04^{\star *}$ & -0.009 & 8.3 & $-0.195^{\star \prime} 0.072^{\star \star}$ & 7.8 & $-0.063^{\star *}$ & -0.012 & 8.3 & $-0.188^{\star \star} 0.064^{\star \star}$ \\
\hline
\end{tabular}


Table 8. Policy interactions, 1985-2013

dependent variable ETCR

log real capital stock

EPL

$\log$ (real capital stock / real output)

ETCR

EPL

base effect interaction base effect interaction base effect interaction base effect interaction

interactions

Product and labour market regulations

\begin{tabular}{l|l} 
ETCR (country average) & -0.011
\end{tabular}

EPL (country average)

PMR \& sub-indicators

aggregate indicator

state control

barriers to entrepreneurship

barriers to trade and investment

$-0.002-0.013^{\star \star}-0.075^{\star \star}-0.194^{\star \star}$

$\begin{array}{llll}0.021^{\star *} & -0.038^{\star *} & -0.144^{\star *} & -0.2^{\star *}\end{array}$

Doing business

contract enforcement - cost -

contract enforcement - time

insolvency costs

insolvency time

insolvency recovery rate

starting a business - cost

starting a business - time

Institutions

rule of law

legal system

Note: as for Table 6a.

\begin{tabular}{|c|c|c|c|c|c|c|c|}
\hline & & & & & & & \\
\hline$-0.016^{\star *}$ & $-0.047^{\star *}$ & $-0.144^{\star \star}$ & $-0.628^{\star \star}$ & $-0.034^{\star *}$ & $-0.087^{\star *}$ & $-0.131^{\star *}$ & $-0.546^{\star \star}$ \\
\hline-0.009 & $-0.018^{\star *}$ & $-0.146^{\star \star}$ & $-0.269^{\star \star}$ & $-0.022^{\star *}$ & $-0.035^{\star \star}$ & $-0.141^{\star \star}$ & $-0.212^{\star \star}$ \\
\hline-0.013 & -0.012 & $-0.104^{\star *}$ & $-0.238^{\star \star}$ & $-0.029 * *$ & $-0.037^{\star *}$ & $-0.094^{\star \star}$ & $-0.258^{\star *}$ \\
\hline$-0.019 * *$ & $-0.027^{\star \star}$ & $-0.184^{\star \star}$ & $-0.176^{\star \star}$ & $-0.035^{\star \star}$ & $-0.033^{\star \star}$ & $-0.174^{\star \star}$ & $-0.174^{\star *}$ \\
\hline-0.012 & -0.00004 & $-0.087^{\star *}$ & $0.018^{\star \star}$ & $-0.021^{\star *}$ & $0.002^{\star \star}$ & $-0.063^{\star \star}$ & $0.021^{\star \star}$ \\
\hline-0.01 & $-2 \mathrm{E}-06$ & $-0.156^{\star \star}$ & -0.0001 & $-0.023^{\star *}$ & $-1 e-05^{\star}$ & $-0.135^{\star \star}$ & 0.0002 \\
\hline$-0.015^{\star \star}$ & $0.001^{* \star}$ & $-0.155^{\star \star}$ & 0.005 & $-0.031^{\star *}$ & $0.002^{\star *}$ & $-0.157^{\star \star}$ & $0.012^{\star *}$ \\
\hline$-0.015^{\star \star}$ & 0.003 & $-0.13^{\star \star}$ & $0.052^{\star \star}$ & $-0.029 * \star$ & $0.018^{\star \star}$ & $-0.098^{\star \star}$ & $0.123^{\star \star}$ \\
\hline-0.012 & $-0.0003^{\star *}$ & $-0.142^{\star \star}$ & -0.001 & $-0.028^{\star *}$ & $-0.0005^{\star \star}$ & $-0.084^{\star \star}$ & $-0.007^{* *}$ \\
\hline-0.007 & $-0.001^{\star *}$ & $-0.099 * *$ & $-0.02^{\star \star}$ & $-0.015^{\star}$ & $-0.003^{\star \star}$ & $-0.087^{* *}$ & $-0.02^{\star \star}$ \\
\hline-0.01 & -0.0001 & $-0.142^{\star \star}$ & -0.0003 & $-0.026^{\star \star}$ & 0.0001 & $-0.154^{\star \star}$ & 0.0003 \\
\hline-0.009 & $0.015^{\star \star}$ & $-0.161^{\star \star}$ & $0.255^{\star \star}$ & $-0.024^{\star \star}$ & $0.022^{\star \star}$ & $-0.151^{\star \star}$ & $0.152^{\star \star}$ \\
\hline-0.01 & $0.013^{* *}$ & $-0.132^{\star \star}$ & $0.104^{\star *}$ & $-0.026^{\star *}$ & $0.017^{* *}$ & $-0.13^{\star \star}$ & $0.073^{\star *}$ \\
\hline
\end{tabular}

Table 9. The impact of policies on the speed of adjustment, 1985-2013

\begin{tabular}{l|l|ll} 
Dependent variable & log real capital stock & log (real capital
\end{tabular} stock / real output)

\begin{tabular}{|c|c|c|c|c|}
\hline ECM term interacted with & ECM term & $\begin{array}{l}\text { ECM with } \\
\text { interaction }\end{array}$ & ECM term & $\begin{array}{l}\text { ECM with } \\
\text { interaction }\end{array}$ \\
\hline \multicolumn{5}{|c|}{ Product and labour market regulations } \\
\hline ETCR (country average) & $-0.092^{\star *}$ & $-0.041^{\star *}$ & $-0.021 * *$ & 0.021 \\
\hline EPL (country average) & $-0.098^{\star \star}$ & $0.011^{\star *}$ & $-0.033^{* *}$ & $0.028^{* *}$ \\
\hline \multicolumn{5}{|l|}{ PMR \& subindicators } \\
\hline aggregate indicator & $-0.092^{* *}$ & $-0.128^{\star *}$ & $-0.021^{* *}$ & 0.028 \\
\hline state control & $-0.092^{* *}$ & -0.021 & $-0.025^{\star *}$ & $0.054^{\star *}$ \\
\hline barriers to entrepreneurship & $-0.104^{\star \star}$ & $-0.142^{\star \star}$ & $-0.019^{*}$ & 0.029 \\
\hline barriers to trade and investment & $-0.091^{\star *}$ & $-0.073^{* *}$ & $-0.021 * *$ & $-0.09 * *$ \\
\hline \multicolumn{5}{|l|}{ Doing business } \\
\hline contract enforcement - cost & $-0.093^{\star *}$ & 0.00003 & $-0.024^{\star *}$ & -0.002 \\
\hline contract enforcement - time & $-0.096 * \star$ & -0.00004 & -0.014 & $0.0002^{\star *}$ \\
\hline insolvency costs & $-0.088^{\star *}$ & $0.002^{*}$ & $-0.022^{* *}$ & 0.0001 \\
\hline insolvency time & $-0.094^{\star \star}$ & -0.002 & $-0.022^{* *}$ & -0.005 \\
\hline insolvency recovery rate & $-0.103^{\star \star}$ & 0.001 & $-0.02^{*}$ & -0.0002 \\
\hline starting a business - cost & $-0.097^{\star *}$ & $-0.008^{\star *}$ & $-0.02^{*}$ & 0.002 \\
\hline starting a business - time & $-0.093^{\star *}$ & 0.0005 & $-0.025^{\star *}$ & $0.003^{\star \star}$ \\
\hline \multicolumn{5}{|l|}{ Institutions } \\
\hline rule of law & $-0.101^{\star *}$ & $0.072^{\star *}$ & $-0.022^{\star *}$ & -0.001 \\
\hline legal system & $-0.099 * *$ & $0.04^{\star *}$ & $-0.022 * *$ & -0.005 \\
\hline
\end{tabular}

Note: as for Table 6a. 


\section{Conclusion}

This paper aimed to analyse the relationship between investment (capital stock) and structural policies including product and labour market regulation. Using a panel of 32 OECD countries for 1985 to 2013, our estimation results show that more stringent product and labour market regulations go hand in hand with a lower capital stock.

We also provide strong empirical evidence for the existence of non-linear effects of product and labour market regulations on the capital stock. Several alternative testing methods show that the negative influence of ETCR and EPL is considerably higher at higher levels of ETCR and EPL, respectively. The implications are that the payoffs of structural reforms are higher for countries with more stringent regulations and that the positive impact of product and labour market deregulation declines once regulations are less biting.

Importantly, we shed light on important policy interactions. We made a strong case for interactions between product and labour market policies. We showed that all types of product market regulations (ranging from State control through barriers to entrepreneurship to barriers to trade and investment) doubles the negative relationship that links product and labour market regulation and the capital stock. Finally, our results indicate that the quality of institutions alters the overall impact of regulations on capital deepening: better insitutions reduces the negative effect of more stringent regulation on the capital stock, probably through the reduction of uncertaintly, so important for investment.

\section{References}

Alesina, A., S. Ardagna, G. Nicoletti, F. Schiantarelly, 2005, Regulation and investment, Journal of the European Economic Association, 3(4), 791-825.

Araújo, S., 2011, Has deregulation increased investment in infrastructure?: Firm-level evidence from OECD countries, OECD Economics Department Working Paper No. 892.

Autor, D. H., W. R. Kerr and A. D. Kugler (2007), Does employment protection reduce productivity? Evidence from US States, Economic Journal, 117(521), 189-217.

Barkbu, B., S. P. Berkmen, P. Lukyantsau, S. Saksonovs and H. Schoelermann (2015), Investment in the euro area: why has it been weak?, IMF Working Papers, No. WP/815/832.

Bassanini, A., S. Scarpetta and P. Hemmings, (2001), Economic growth: the role of policies and institutions: panel data evidence from OECD from OECD countries, OECD Economics Department Working Paper No. 283.

Bond S.and C. Meghir, 1994, Dynamic investment models and the firm's financial policy, The Review of Economics Studies, 61(2), 197-222.

Cambini, C and L. Rondi (2011), Regulatory independence, investment and political inference: Evidence from the European Union, RSCAC Working Paper 2011/42, European University Institute.

Cette, G., J. Lopez and J. Mairesse (2016), Labour market regulations and capital intensity, NBER Working Papers No. 22603. 
Cingano, F., M. Leonardi, J. Messina and G. Pica (2010), The effect of employment protection legislation and financial market imperfections on investment: evidence from a firm-level panel of EU countries, Economic Policy, 25(61), 117-63.

Cingano, F., M. Leonardi, J. Messina and G. Pica (2015), Employment protection legislation, capital investment and access to credit: evidence from Italy, Economic Journal, doi:10.1111/ecoj.12212

Chirinko, R. (1993), "Business fixed investment spending: modelling strategies, empirical results, and policy implications”, Journal of Economic Literature, Vol. 31(4), pp. 1875-1911.

Égert, B., 2009, Infrastructure investment in network industries: the role of incentive regulation and regulatory independence, OECD Economics Department Working Paper No. 688.

Gal, P. and A. Theising (2015), The macroeconomic impact of structural policies on labour market outcomes in OECD countries: a reassessment, OECD Economics Department Working Paper (forthcoming)

Ghura, D. and B. Goodwin, 2010, Determinants of private investment: a cross-regional empirical investigation, Applied Economics, 32(14), 1819-1829.

Im, K.S., M. J. Pesaran and Y. Shin (2003), Testing for unit roots in heterogeneous panels. Journal of Econometrics, 115(1), 53-74.

Kao, C. (1999), Spurious regression and residual-based tests for cointegration in panel data, Journal of Econometrics, 90(1), 1-44.

Kedrain, C., I. Koske, I. Wanner (2010), The impact of structural policies on saving, investment and current accounts, OECD Economics Department Working Papers No. 815.

Lee, J. and P. Rabanal (2010), “Forecasting U.S. investment”, IMF Working Papers, No. WP/10/246.

Levin, A., C-F. Lin and C-S. J Chu (2002), Unit root tests in panel data: Asymptotic and finite-sample properties, Journal of Econometrics, 108 (1), 1-24.

Lim, J.J. (2014), Institutional and structural determinants of investment worldwide, Journal of Macroeconomics, 41, 160-177.

Oliner, S., G. Rudebusch and D. Sichel (1995), “New and old models of business investment: a comparison of forecasting performance”, Journal of Money, Credit and Banking, Vol. 27(3), pp. 806-826.

Pelgrin, F., S. Schich and A. de Serres (2002), Increase in business investment rates in OECD countries in the 1990s: How much can be explained by the fundamentals? OECD Economics Department Working Paper No. 327.

Philippon, T. (2009), “The bond market’s Q”, The Quarterly Journal of Economics, Vol. 124(3), pp. 10111056.

Salotti, S. and C. Trecroci, 2012, Even worse than you thought: the impact of public debt on aggregate investment and productivity, DEFIT Conference Papers c017_020. 
Sharpe, S. A. and G. A. Suarez (2014), “The sensitivity of investment to interest rates: Evidence from a survey of CFOs”, Federal Reserve Board, Finance and Economics Discussion Series, No. 2014-02.

Stock, J. and M. Watson (1993), “A simple estimator of cointegrating vectors in higher order integrated systems”. Econometrica, 61 (4), 783-820.

Tevlin, S. and K. Whelan (2003), “Explaining the investment boom in the 1990s”, Journal of Money, Credit and Banking, Vol. 35(1), pp. 1-22.

Vartia, L. (2008), How do taxes affect investment and productivity? - An industry-level analysis of OECD countries, OECD Economics Department Working Paper No. 656.

World Bank (2014), Research on the effects of business regulation.

http://www.doingbusiness.org/reports/global-

reports/ /media/GIAWB/Doing\%20Business/Documents/Annual-Reports/English/DB14-

Chapters/DB14-Research-on-the-effects-of-business-regulations.pdf 